WSRC-TR-96-0175, Rev. 1

\title{
Sampling and Analysis of Pond 2, Pond 5, and the P-Reactor Canal Sediments
}

by

N. V. Halverson

Westinghouse Savannah River Company

Savannah River Site

Aiken, South Carolina 29808

J. V. Noonkester

This paper was prepared in connection with work done under the above contract number with the U.S. Department of Energy. By acceptance of this paper, the publisher and/or recipient acknowledges the U.S. Government's right to retain a nonexclusive, royalty-free license in and to any copyright covering this paper, along with the right to reproduce and to authorize others to reproduce all or part of the copyrighted paper. 
Rev. 1

\section{Sampling and Analysis of Pond 2, Pond 5, and the P-Reactor Canal Sediments}

by

N. V. Halverson and J. V. Noonkester

Westinghouse Savannah River Company

Aiken, SC 29808

June 1996

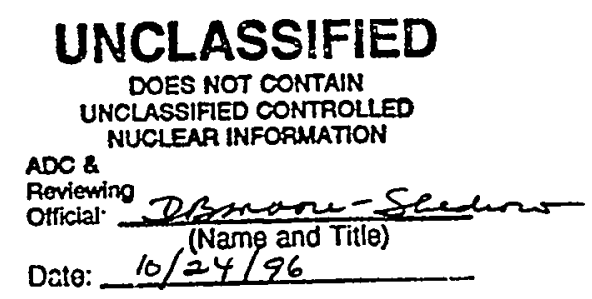

The information contained in this report was developed during the course of work under Contract No. DE-AC09-89SR18035 with the U.S. Department of Energy. 


\section{DISCLAIMER}

This report was prepared as an account of work sponsored by an agency of the United States Government. Neither the United States Government nor any agency thereof, nor any of their employees, makes any warranty, express or implied, or assumes any legal liability or responsibility for the accuracy, completeness, or usefulness of any information, apparatus, product, or process disclosed, or represents that its use would not infringe privately owned rights. Reference herein to any specific commercial product, process, or service by trade name, trademark, manufacturer, or otherwise does not necessarily constitute or imply its endorsement, recommendation, or favoring by the United States Government or any agency thereof. The views and opinions of authors expressed herein do not necessarily state or reflect those of the United States Government or any agency thereof.

This report has been reproduced directly from the best available copy.

Available to DOE and DOE contractors from the Office of Scientific and Technical Information, P.O. Box 62, Oak Ridge, TN 37831; prices available from (615) 576-8401.

Available to the public from the National Technical Information Service, U.S. Department of Commerce, 5285 Port Royal Road, Springfield, VA 22161. 


\section{DISCLAIMER}

Portions of this document may be illegible in electronic image products. Images are produced from the best available original document. 


\section{Table of Contents}

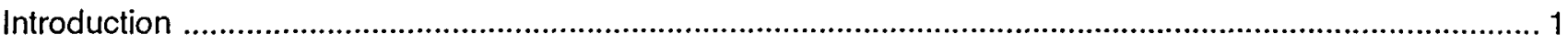

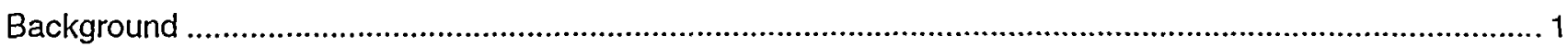

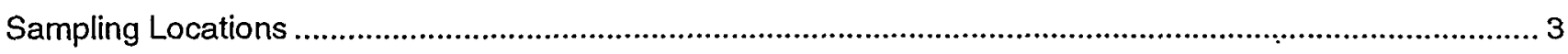

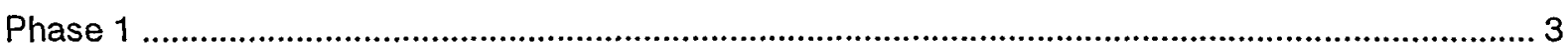

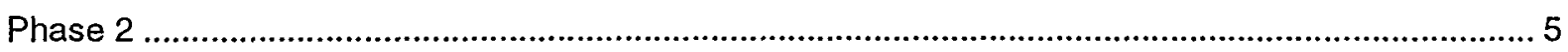

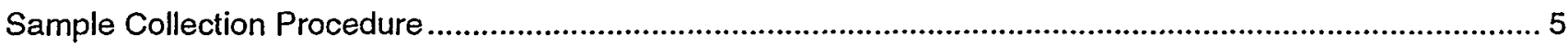

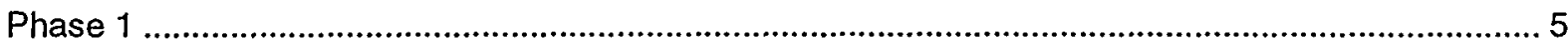

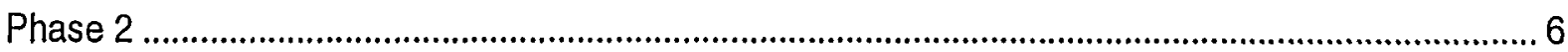

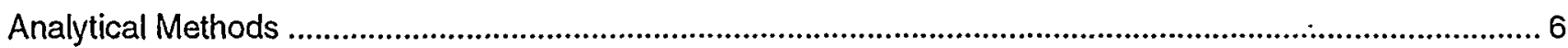

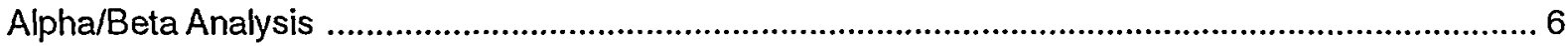

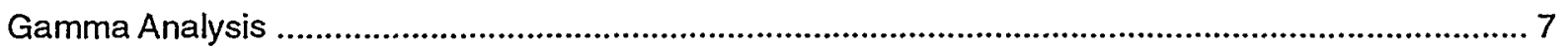

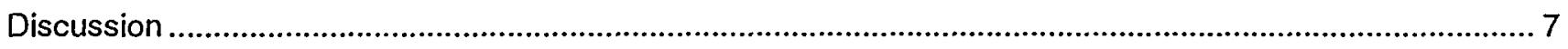

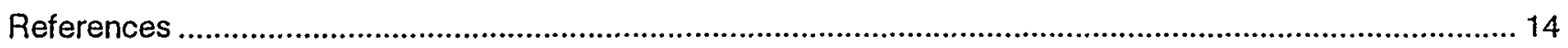

Appendix A: GPS Coordinates for All Sampling Transects

Appendix B: Analytical Detection Limits

Appendix C: Results 


\section{List of Figures}

Figure 1.

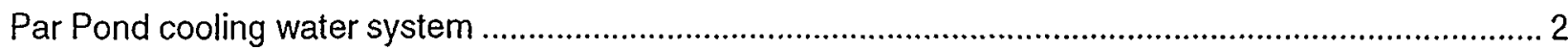

Figure 2.

Pond 2, Pond 5, and P-Reactor canal sampling locations .................................................................. 4

\section{List of Tables}

Table 1.

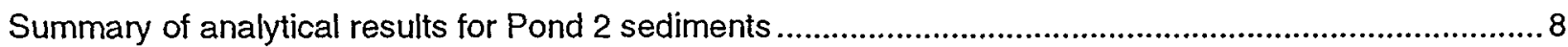

Table 2

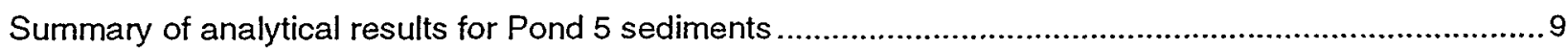

Table 3.

Summary of analytical results for P-Reactor canal sediments 10

Table 4.

Comparison of activity levels measured in the P-Reactor canal system in this study and in other Par Pond cooling system studies 


\title{
Sampling and Analysis of Pond 2, Pond 5 and the P-Reactor Canal Sediments
}

\author{
N. V. Halverson and J. V. Noonkester \\ Westinghouse Savannah River Company \\ Savannah River Technology Center \\ Environmental Sciences Section \\ Aiken, SC 29808 .
}

\section{Introduction}

The shutdown of the Savannah River Site's (SRS) river water distribution system is expected to cause fluctuating water levels in Par Pond and its precooling ponds and canals. The entire Par Pond system is contaminated with radioisotopes released during reactor operations in the 1950s and 1960s. In support of an environmental impact statement to determine the consequences of shutting down the river water distribution system, sediment samples from Pond 2, Pond 5, and the P-Reactor canal were collected from above and below the existing water line. Samples were analyzed for gross alpha, gross beta, and gamma activity. The intent was not to characterize the ponds and canal, but to identify the maximum levels of contamination that could be exposed by fluctuating water levels and determine whether those levels exceed levels used in risk assessments of exposed Par Pond sediments. This report discusses the procedures used to perform the sampling, the methods used to analyze the samples, and the results.

\section{Background}

The U.S. Department of Energy Savannah River Operations Office Strategic Plan requires SRS organizations to find ways to reduce operating costs and to decide what portion of the SRS infrastructure must be maintained and what portion can be eliminated. Because of SRS mission changes in recent years, the Par Pond and river water pumping systems are no longer needed to support SRS programs. Therefore, the shut down of these systems provides an opportunity for cost reduction (DOE 1995a).
When the SRS reactors began operating in the early 1950s, R Reactor received cooling water directly from the Savannah River and discharged cooling water directly into Lower Three Runs in an area that is now the Hot Arm of Par Pond. P Reactor received cooling water directly from the Savannah River and discharged cooling water directly into Steel Creek (DOE 1995b).

In 1958, Par Pond was created by constructing an earthen dam on Lower Three Runs (Figure 1). The 1012-hectare (2500-acre) recirculating cooling water reservoir was built to dissipate heat from cooling water effluent discharged from $\mathrm{P}$ and $\mathrm{R}$ Reactors (DOE 1995a). In 1958, the cooling water effluent pathway from $\mathrm{R}$ Reactor was rerouted through Pond $\mathrm{C}$ to the Hot Arm of Par Pond. In 1961, R-Reactor cooling water began to be discharged to Par Pond through the newly constructed $\mathrm{R}$ Canal and Pond $\mathrm{B}$. This water discharge system was used until R Reactor was shut down in 1964. P Reactor began discharging to Par Pond in 1961. The cooling water was discharged through a series of canals and precooler ponds to Pond $\mathrm{C}$ and then to Par Pond (Wike et al. 1994). Pond 2, Pond 5, Pond C, and the canals connecting these ponds to P Reactor make up the P-Reactor canal system. Parts of the P-Reactor canal system follow the original R-Reactor drainage system (DOE 1995a). P Reactor continued to discharge cooling water into Par Pond via the canal system until the reactor was shut down in 1988 (DOE 1995b).

Even with the recirculating cooling system, water from the Savannah River was still needed to replace water lost from Par Pond by evaporation and 


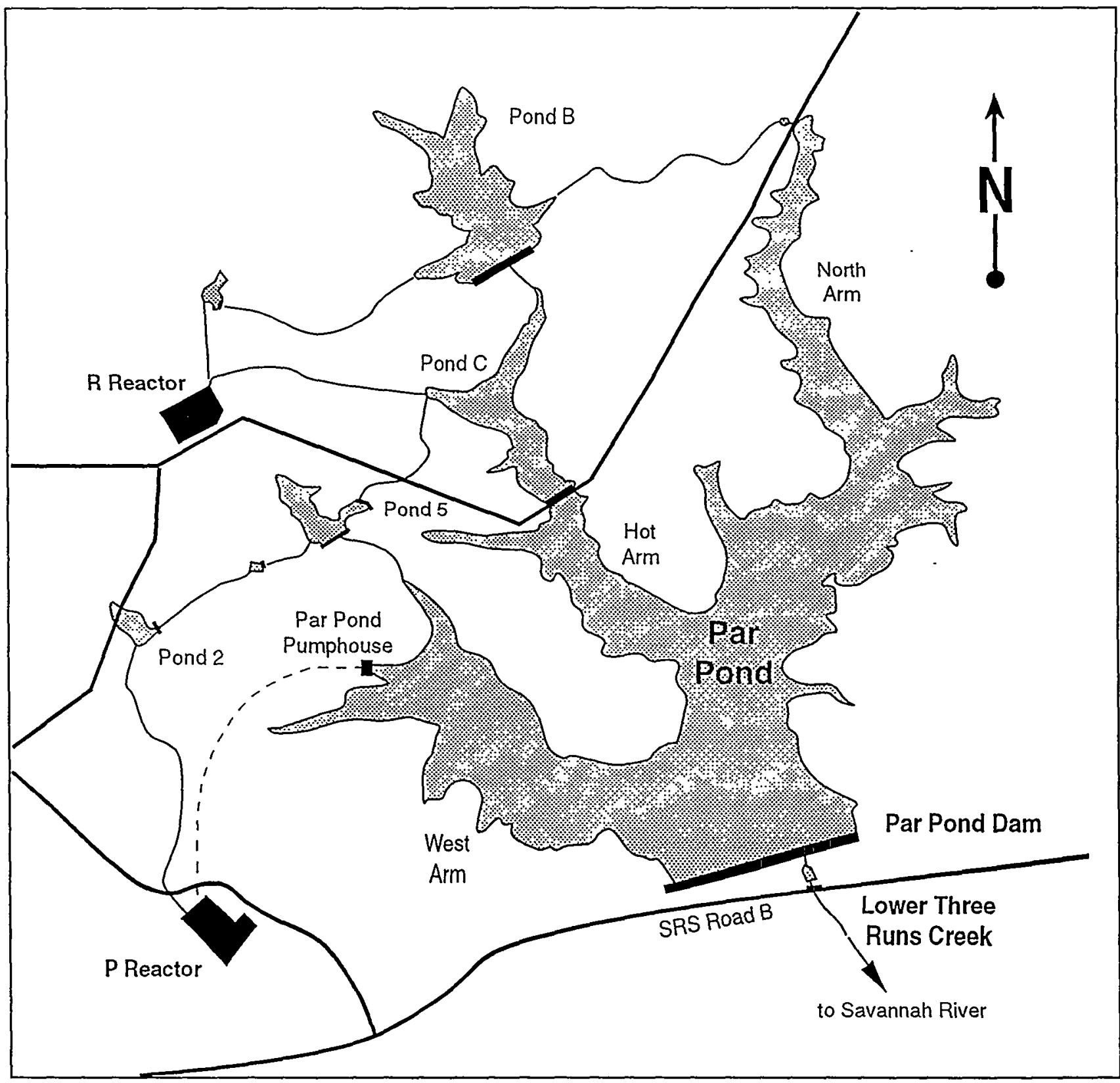

Figure 1. Par Pond cooling water system.

seepage. River water was mixed in basins at the reactor areas with recirculated water from Par Pond before it was pumped through the reactor secondary cooling system. The secondary cooling water, which was pumped to Par Pond, circulated through a system separate from the radioactive primary cooling water. Excess water from Par Pond drained to the Savannah River via Lower Three Runs (DOE 1995b).
Releases in the form of process leaks and purges have contaminated Par Pond and its associated precooling ponds with cesium-137 and other radioactive constituents. Makeup cooling water from the Savannah River has contaminated the system with nonradioactive constituents. All radioactive releases ceased when $R$ Reactor was shut down in 1964. Although P Reactor released no measurable cesium-137 into Par Pond (DOE 1995b), parts of 
the P-Reactor canal system, including Pond 5, received releases from $R$ Reactor prior to the construction of Par Pond (DOE 1995a). In addition, the P-Reactor canal and precooler ponds have received secondary cesium-137 contamination as a result of recirculating contaminated cooling water from Par Pond through the reactor facilities to the discharge canal and precooler ponds and back to Par Pond (DOE 1995b). However, it is likely that historically high flows through the canals prevented significant accumulation of contaminants (DOE 1995a).

Since the reservoir was constructed, river water influent has been adjusted to maintain Par Pond at full pool, keeping contaminated sediments submerged (DOE 1995a). In June 1995, the U.S. Department of Energy prepared an environmental assessment to evaluate the impacts of reducing the pumping of river water to Par Pond and allowing the water level in the reservoir to fluctuate naturally. A Finding of No Significant Impact was approved on August 29, 1995 (WSRC 1996), meaning there was no indication from the information evaluated in the environmental assessment that ceasing to pump water to Par Pond would adversely impact the ecology of the reservoir. The proposed action was to reduce pumping to Par Pond and allow the water level to fluctuate naturally between full pool (61 meters [m] [200 feet] above mean sea level) and $58 \mathrm{~m}$ (195 feet above mean sea level). The environmental assessment compared potential impacts of the proposed action to impacts measured during a 1991-1995 drawdown of Par Pond (DOE 1995a).

The effects of reduced water levels in the P-Reactor canal system were not evaluated during the 1991 drawdown of Par Pond. The precooler ponds were constructed by impounding natural drainages, which allow them to receive rainfall and surface and near-surface runoff. Therefore, cessation of water discharge through the canals is not expected to cause total drying of the precooler ponds except in a severe drought. Estimates of the contamina- tion levels in the sediments of the precooler system have not been available because the P-Reactor canal system has not been surveyed or sampled in detail (DOE 1995a).

\section{Sampling Locations}

During this study, sediment samples were collected in August 1995 (Phase 1) and April 1996 (Phase 2) at four sites in Pond 2, eight sites in or near Pond 5, and one site along the canal between Pond 2 and Pond 5. Phase 2 sampling was initiated because an examination of the Phase 1 results indicated higher-than-expected contamination at some locations and because a reexamination of the gamma contours from aerial survey data identified additional locations with contamination.

\section{Phase 1}

During the first sampling phase, sediment samples were collected from Pond 2 and Pond 5. Sampling sites were determined based on contour maps of gamma radiation exposure rates at $1 \mathrm{~m}$ (3.3 feet) above ground level. The maps were constructed from 1991 radiological survey aerial data overlaid on a United States Geological Survey map of the area. Sites with measurable gamma radiation were chosen for sampling.

Pond 2 had three Phase 1 sampling sites (Figure 2). The first site (P2-1) was on the east side of the pond, near the canal. The second sampling site (P2-2) was farther north, but on the same side of the pond. Sample site P2-3 was located near the northwest corner of the pond.

Pond 5 had five Phase 1 sampling sites (Figure 2). P5-1 was on the far northeast arm of the pond, near the outlet canal. P5-2 was on the south side of the pond, just east of the inlet canal. P5-3 was along the north shore of the northeast arm, southwest of P5-1. P5-4 was on the northeast shore of the northwest arm, west of P5-3. P5-5 was along the west shore of the northwest arm of the pond. 

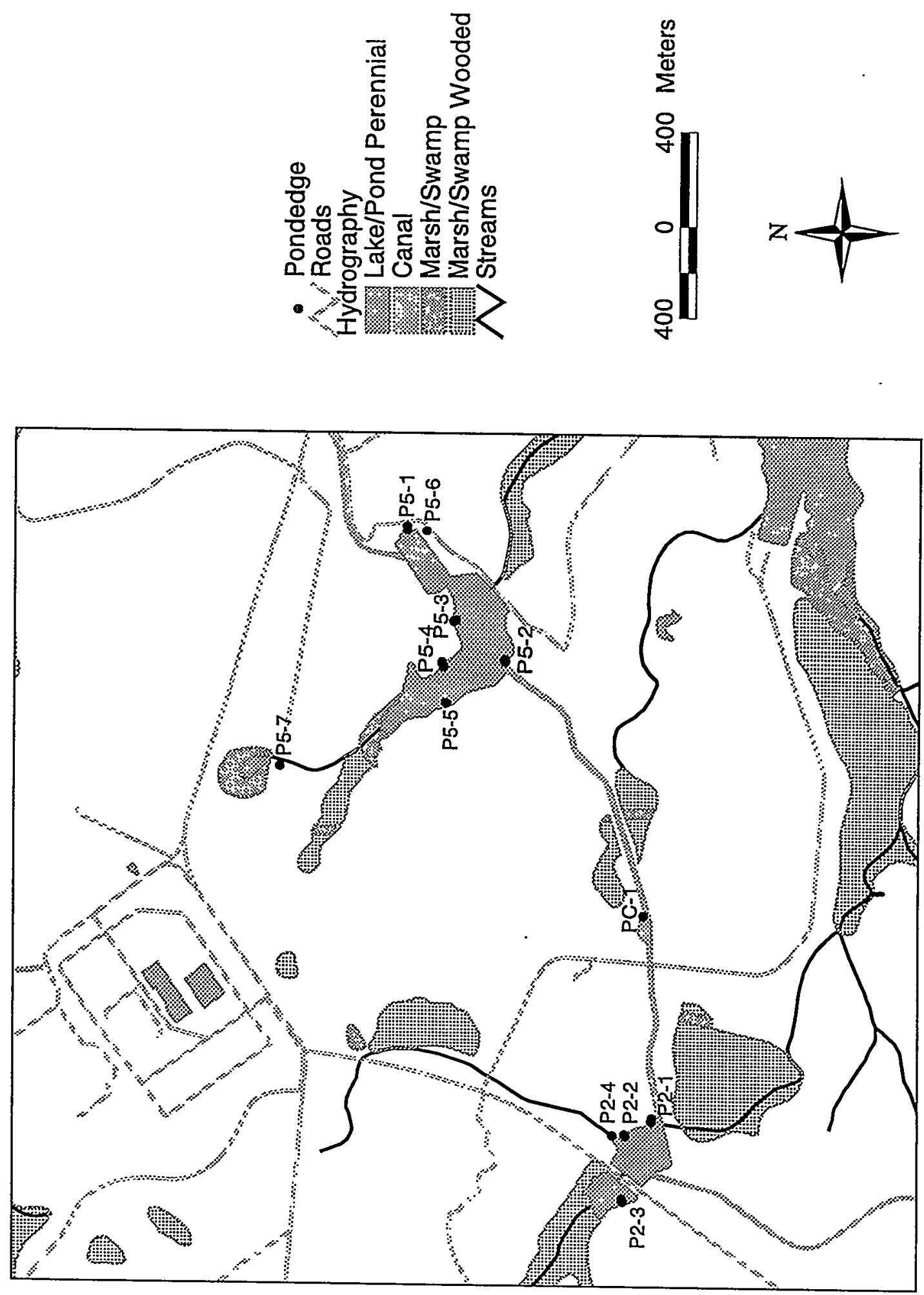

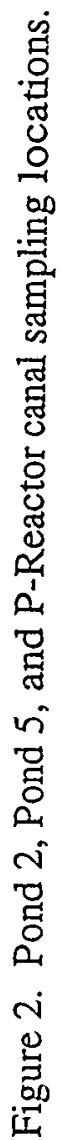


After Phase 1 sampling was completed, Geographic Positioning System (GPS) was used to determine coordinates for the sampling points. At each transect, coordinate points were determined for the sample points at either end of the transect. The coordinates are listed in Appendix A.

\section{Phase 2}

Transect locations from Phase 1 were compared with the contour maps showing gamma radiation exposure. Additional sampling locations were selected for Phase 2 in areas of the ponds and canal that were not sampled in Phase 1 but showed elevated activity on the contour maps. In Pond 2, a new sampling site was located on the northeast side of the pond, at the mouth of a small stream and designated P2-4. In Pond 5, a new sampling site was located on the southeast shore of the northeast arm and was designated P5-6 (Figure 2).

Two other sampling locations were chosen along a natural drainage swale northwest of Pond 5 . The first site, designated P5-7, was a wet spot near a culvert under an access road. The second site, P58 , was along the swale close to Pond 5 (Figure 2).

In addition, a wide spot in the P-Reactor discharge canal between Pond 2 and Pond 5 was sampled in Phase 2. The canal transect was designated PC-1 (Figure 2). This location had gamma activity on various aerial gamma survey maps. Also, sediments collected during Phase 1 at P5-4-7 and P5 48 were reanalyzed because of the higher radioactivity detected in the Phase 1 analysis of these points as compared to the other sample points. GPS was used to determine coordinates for the Phase 2 sampling points. The coordinates are listed in Appendix A.

\section{Sample Collection Procedure}

Samples were collected by Westinghouse Savannah River Company (WSRC) Environmental Sci- ences Section personnel. Samples were taken with either a hand auger or a shovel, whichever was more efficient. Usually, the auger was used to collect sediment from under water and the shovel was used on land. Each sample consisted of sediment collected from approximately the top $8 \mathrm{~cm} \mathrm{(3}$ inches) of soil.

\section{Phase 1}

At each pond, screening samples were collected first to determine whether Radiological Control Operations (RCO) coverage would be required for the remainder of the sampling activity. Radioactivity was below screening limits for all samples, with concentrations of less than 36 picoCuries per gram (pCi/g) beta-gamma and less than $4.5 \mathrm{pCi} / \mathrm{g}$ alpha activity. Therefore, $\mathrm{RCO}$ coverage was not required.

A transect was established at each site. One end of each transect was at the 50-centimeter ([cm] 20inch) water depth; the other was on the shore at an elevation of $30 \mathrm{~cm}$ (12 inches) above the water's edge. Sampling points were established along each transect at water depths of $50 \mathrm{~cm}$ (30 inches), 40 $\mathrm{cm}$ (16 inches), $30 \mathrm{~cm}$ (12 inches), $20 \mathrm{~cm}$ (8 inches), $10 \mathrm{~cm}$ (4 inches), and $0 \mathrm{~cm}$ (water's edge) and marked with PVC pipe labeled with the transect and sample point number. Labeled flags were used to mark the sampling points on the land portion of the transect at approximately $10 \mathrm{~cm}(4$ inch), $20 \mathrm{~cm}$ ( 8 inch), and $30 \mathrm{~cm}^{-}$(12 inch) elevations above the water's edge. The elevation changes on the shore were estimated. Sampling points were numbered according to the transect and sample point, moving from the water toward the shore. At each transect, the sample at the $50-\mathrm{cm}$ (30-inch) depth was Sample 1. The shoreline sample (0-cm depth) was Sample 6. The land samples were labeled Samples 7, 8, and 9. For example, the sample point at the $50-\mathrm{cm}$ (20-inch) depth on transect P2-1 was designated P2-1-1. Duplicate samples were collected at sample points 1 and 7 at each transect. 
At each of the 3 Phase 1 transects in Pond 2, 11 samples were collected ( 9 sample points and 2 duplicates) for a total of 33 samples. At each of the 5 Phase 1 transects in Pond 5, 11 samples were collected (9 sample points and 2 duplicates) for a total of 55 samples.

The nine samples (numbered -1 through -9) from each transect were delivered to the WSRC Environmental Monitoring Section (EMS) for gamma spectroscopy analysis. EMS provided subsamples of each sample to the WSRC Analytical Development Section (ADS) for gross alpha and nonvolatile beta analysis. The two duplicates from each transect (-1D and -7D) were delivered separately to ADS for gamma spectroscopy, gross alpha, and nonvolatile beta analysis. Therefore, for each sample (-1 through -9) from each transect, EMS performed the gamma spectroscopy and $\mathrm{ADS}$ performed the gross alpha and nonvolatile beta analyses. For each duplicate sample, ADS performed all three analyses.

\section{Phase 2}

Three samples were collected from each of the 5 new locations, a total of 15 samples. No duplicates were collected.

Samples at P2-4 and P5-8 were collected from under shallow water. Samples from P5-6 and P5-7 were taken near, but above, the water's edge. In the canal, samples $\mathrm{PC}-1-1$ and $\mathrm{PC}-1-2$ were taken from underwater, and sample PC-13 was taken from above the water's edge. Labeled flags marked the locations of the Phase 2 samples.

In addition, residual soil from samples P5-4-7 and P5-4-8 collected during Phase 1 was resubmitted for analysis in Phase 2.

Gamma spectroscopy, gross alpha, and nonvolatile beta analysis were performed on the Phase 2 samples by ADS.
Analytical Methods

\section{Alpha/Beta Analysis}

ADS performed radiological screening analyses for alpha and beta activity on all the samples. The samples were prepared for analysis by leaching approximately 1.5 grams ( 0.5 ounces) of soil in concentrated nitric acid in a microwave oven. This process aggressively leaches both man-made and naturally occurring radioisotopes from the soil to the nitric acid. However, volatile species, such as tritium, are lost during this process. The nitric acid leachate was analyzed for radioactivity in a Packard Instruments Model 2250/CA Liquid Scintillation Counter, which is capable of separating the alpha and beta portions of the total activity (Peterson 1995). The scintillation counter counts radioactive disintegrations per minute as a measure of radioactivity present in the sample.

The samples were analyzed in four sets; the original and duplicate samples were run in two sets each. Before each set of samples was analyzed, an instrument blank was analyzed to establish the instrument background that was factored into the calculations of the count results for the samples to ensure an accurate assessment of radioactivity in the samples. Detection limits are provided in Appendix $B$. More than one detection limit was reported for gross alpha and nonvolatile beta.

Duplicate and all Phase 2 samples results were originally reported as dry weights, but the remaining sample results were reported as wet weights. The dry weights were converted to wet weights to make all results consistent. Converting the wet weight results to equivalent dry weight results would have been preferable, but was not possible because soil moisture content was not available for the Phase 1 samples. Results for Phase 1 and Phase 2 samples were reported in picoCuries per gram (pCi/g), while the results of the duplicate samples were reported in disintegrations per minute per gram. The results for the duplicates were converted 
to $\mathrm{pCi} / \mathrm{g}$ to make all results consistent. Appendix C, Table 1, summarizes the units reported by each laboratory for the various samples. The table also shows the equations used to convert the data to consistent units.

\section{Gamma Analysis}

Each sample processed by EMS for gamma spectroscopy analysis was dried for approximately 24 hours at $105^{\circ} \mathrm{C}\left(221^{\circ} \mathrm{F}\right)$, weighed, sifted through a 3.5-inch mesh sieve, blended for one hour, and pulverized. About 500 milliliters (approximately $600 \mathrm{~g}$ [21 ounces]) of the pulverized sample was analyzed for 5000 seconds on a high purity germanium detector that has an efficiency usually greater than $30 \%$. Results were reported as dry weight (Crandall 1996).

Each sample ADS analyzed for gamma spectroscopy also was analyzed on a high purity germanium detector (Diprete 1995). A 200-g (7-ounce) aliquot of each sample was counted for $3600 \mathrm{sec}-$ onds. The results were corrected for instrument background and were reported as wet weight. These results were converted to the equivalent dry weight measurements using the equations shown in Appendix C, Table C-1.

The constituents analyzed by each laboratory, along with their typical minimum detection limits, are provided in Appendix B. A range of detection limits is provided for some constituents. Detection limits can vary from one sample to the next based on a variety of factors. Thus, detection limits for some samples from this study actually may be outside of the "typical" ranges reported here.

\section{Discussion}

Analytical results for Pond 2, Pond 5, and the PReactor canal are presented in Tables 1,2, and 3, respectively. Mean values were calculated using only those samples with activities above the lower limit of detection. The ranges and means in the tables are not representative of the P-Reactor cooling system as a whole because samples were collected only from areas where elevated activity levels were expected. The intent was not to characterize the ponds and canal, but to identify the maximum levels of contamination that could be exposed with a drawdown and determine whether those levels exceed levels used in Par Pond risk assessments.

Three samples from Pond 2 and 11 samples from Pond 5 had low levels of gross alpha activity. The levels in the two ponds were comparable (Tables 1 and 2; Appendix C, Tables C-2, C-3, C-4, C-5, C-6, C-7, C-8, C-9, C-10, C-11, C-12, and C-13).

Nonvolatile beta activity was measured in most of the Pond 2 and the P-Reactor canal samples, but was found in less than half the Pond 5 samples. However, the Pond 5 samples had higher activity than the other samples (Tables 1,2, and 3). The highest activity was at P5-4 (Appendix C, Table $\mathrm{C}-9$ ), where activities of $71 \mathrm{pCi} / \mathrm{g}, 110 \mathrm{pCi} / \mathrm{g}$, and $240 \mathrm{pCi} / \mathrm{g}$ were recorded and at P5-6, where activities of $95 \mathrm{pCi} / \mathrm{g}$ and $130 \mathrm{pCi} / \mathrm{g}$ were recorded (Appendix C, Table C-11).

The method of analysis ADS used for gross alpha and nonvolatile beta is a good qualitative indicator of the presence or absence of radioactivity in soil samples. However, due to sampling and counting limitations, the absolute quantities determined by this method may be subject to large errors. Uncertainty based on counting statistics and other sources of error was about $\pm 100 \%$ (Peterson 1995).

Gamma spectroscopy results indicated that some samples contained the following naturally occurring radioisotopes: beryllium-7, potassium- 40 , thallium-208, lead-212, lead-214, bismuth-212, bismuth-214, radium-224, radium-226, actinium228 , thorium-228, thorium-231, thorium-234, and uranium-235. The only manmade radioisotopes found in any of the samples were cobalt- 60 , cesium-137, europium-155, and americium-241 (DiPrete 1995; Crandall 1995). Cesium-137 was 
Table 1. Summary of analytical results for Pond 2 sediments (pCi/g).

\begin{tabular}{|c|c|c|c|}
\hline Analyte & Number 1 & $\begin{array}{l}\text { Range } \\
\text { (pCi/g) }\end{array}$ & $\begin{array}{l}\text { Average } \\
(\mathrm{pCi} / \mathrm{g})^{2}\end{array}$ \\
\hline ४ै. & & \% & \\
\hline Gross alpha & 3 & $<2.5-7.6$ & 5.2 \\
\hline Nonvolatile beta & 27 & $<5.8-35$ & 17 \\
\hline Potassium- 40 & 29 & $N D^{3}-4.10$ & 1.79 \\
\hline Cobalt-60 & 4 & ND-0.121 & 0.0893 \\
\hline Cesium-137 & 36 & $0.987-23.9$ & 6.21 \\
\hline Thallium-208 & 36 & $0.0976-0.691$ & 0.366 \\
\hline Lead-212 & 36 & $0.281-2.11$ & 1.06 \\
\hline Lead-214 & 35 & ND-1.49 & 0.914 \\
\hline Bismuth-212 & $24^{\circ}$ & ND-3.01 & 1.04 \\
\hline Bismuth-213 & 36 & $0.120-2.53$ & 0.893 \\
\hline Radium-224 & 3 & ND-3.20 & 2.67 \\
\hline Radium-226 & 18 & ND-5.99 & 3.13 \\
\hline Actinium-228 & 30 & ND-2.32 & 1.07 \\
\hline Thorium-228 & 4 & ND-5.11 & 4.46 \\
\hline Thorium-231 & 4 & ND-0.964 & 0.843 \\
\hline Thorium-234 & 7 & ND-2.22 & 1.49 \\
\hline Uranium-235 & 2 & ND-0.362 & 0.266 \\
\hline Americium-241 & 1 & 0.881 & 0.881 \\
\hline
\end{tabular}

1 Number of samples with measurable concentrations of the analyte. Thirty-six samples were analyzed.

2 Only those samples with measurable activity were averaged.

$3 \mathrm{ND}=$ Not detected.

detected in all but four samples. Six samples showed the presence of cobalt-60, one sample indicated the presence of europium-155, and one sample indicated the presence of americium-241 (Appendix C).

Cesium- 137 detected in the sediment samples from Pond 2 ranged from 0.987 to $23.9 \mathrm{pCi} / \mathrm{g}$. The highest concentration was at P2-4. P-Reactor canal samples ranged from 0.137 to $23.7 \mathrm{pCi} / \mathrm{g}$. In Pond 5 samples, cesium-137 ranged from less than detectable to $87.4 \mathrm{pCi} / \mathrm{g}$. The highest concentration in Pond 5 was at P5-4. The samples with the highest concentrations were collected $10-20 \mathrm{~cm}$ (4-8 inches) above the water line. The sample points with the highest concentrations of cesium- 137 also had the highest nonvolatile beta activity, as expected (Appendix C). 
Table 2. Summary of analytical results for Pond 5 (pCi/g).

\begin{tabular}{|c|c|c|c|}
\hline Analyte & Number ${ }^{1}$ & $\begin{array}{l}\text { Range } \\
(\mathrm{pCi} / \mathrm{g})\end{array}$ & $\begin{array}{l}\text { Average } \\
\text { (pCi/g) }^{2}\end{array}$ \\
\hline 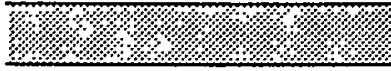 & \% \% : & \% & א. \\
\hline Gross alpha & 11 & $<2.6-9.4$ & 4.9 \\
\hline Nonvolatile beta & 30 & $<5.9-240$ & 37 \\
\hline Beryllium-7 & 1 & 1.81 & 1.81 \\
\hline Potassium-40 & 35 & $N D^{3}-9.44$ & 2.04 \\
\hline Cobalt-60 & 2 & ND-0.176 & 0.118 \\
\hline Cesium-137 & 60 & ND-87.4 & 11.8 \\
\hline Europium-155 & 1 & 0.215 & 0.215 \\
\hline Thallium-208 & 56 & ND-0.940 & 0.372 \\
\hline Lead-212 & 61 & ND-2.36 & 0.971 \\
\hline Lead-214 & 63 & $0.0669-3.01$ & 0.836 \\
\hline Bismuth-212 & 37 & ND-2.85 & 1 \\
\hline Bismuth-214 & 60 & ND-1.82 & 0.796 \\
\hline Radium-224 & 11 & ND-2.76 & 1.78 \\
\hline Radium-226 & 22 & ND-8.05 & 2.68 \\
\hline Actinium-228 & 47 & ND-2.46 & 1.15 \\
\hline Thorium-228 & 4 & ND-11.1 & 6.75 \\
\hline Thorium-231 & 3 & ND-2.10 & 1.28 \\
\hline Thorium-234 & 5 & ND-2.81 & 1.96 \\
\hline Uranium-235 & 5 & ND-0.220 & 0.140 \\
\hline
\end{tabular}

1 Number of samples with measurable concentrations of the analyte. Sixty-seven famples were analyzed.

2 Only those samples with measurable activity were averaged.

$3 \mathrm{ND}=$ Not detected.

Cobalt- 60 was detected in both ponds, and detectable concentrations ranged from $0.0569 \mathrm{pCi} / \mathrm{g}$ to $0.176 \mathrm{pCi} / \mathrm{g}$. Americium-241 was found only at transect P2-1 and measured $0.881 \mathrm{pCi} / \mathrm{g}$. Historically, EMS has not detected cobalt-60 or americium-241 in non-SRS soils. Therefore, the cobalt60 and americium-241 measured in the P-Reactor cooling water system could be considered to ex- ceed background values (Crandall 1996). However, based on information in Lower (1987), the cobalt -60 values are within the range associated with global fallout.

Gamma spectroscopy is not the recommended method for quantifying some naturally occurring radioisotopes, including radium-224, radium-226, 
Table 3. Summary of analytical results for the P-Reactor Canal sediments (pCi/g).

\begin{tabular}{|c|c|c|c|}
\hline Analyte & Number 1 & $\begin{array}{l}\text { Range } \\
\text { (pCi/g) }\end{array}$ & $\begin{array}{l}\text { Average } \\
\text { (pCi/g) } 2\end{array}$ \\
\hline Nonvolatile beta & 2 & $<7.9-54$ & 39 \\
\hline Potassium-40 & 1 & 4.65 & 4.65 \\
\hline Cesium-137 & 3 & $0.137-23.7$ & 8.23 \\
\hline Thallium-208 & 3 & $0.287-0.556$ & 0.414 \\
\hline Lead-212 & 3 & $0.654-1.48$ & 1.065 \\
\hline Lead-214 & 3 & $0.556-0.16$ & 0.770 \\
\hline Bismuth-212 & 2 & $N D^{3}-1.88$ & 1.59 \\
\hline Bismuth-214 & 3 & $0.523-1.42$ & Q.855 \\
\hline Radium-224 & 1 & 1.03 & 1.03 \\
\hline Actinium-228 & 3 & $0.639-1.44$ & 1.01 \\
\hline
\end{tabular}

1 Number of samples with measurable concentrations of the analyte. Three samples were analyzed.

2 Only those samples with measurable activity were averaged.

$3 \mathrm{ND}=$ Not detected.

thorium-228, thorium-231, thorium-234, and uranium-235, in environmental samples. Chemical separation and concentration of the radionuclides would be the preferred method. Therefore, the data reported for these isotopes should be used only for information and trending (Crandall 1996). Gamma spectroscopy is the recommended method for quantification of the naturally occurring radioisotopes thallium-208, lead-212, lead-214, bismuth-212, and actinium-228 (Crandall 1996).

For some of the samples analyzed by ADS, a gamma ray with a particular energy that could be attributed to more than one radionuclide (radium226 or uranium-235) was observed. The instrument software could not discern whether one or both radionuclides were present or determine the ratio of the two. In these instances, all the activity was assigned to each of the radionuclides. These instances are identified in the Appendix $\mathrm{C}$ tables with the footnote "Part of an ADS undetermined solution" (Diprete 1996).

Although the P-Reactor cooling water canal system has not previously been studied, numerous studies of Par Pond, Pond B, and Pond $C$ have been performed. Table 4 compares cesium-137, cobalt60 , gross alpha and nonvolatile beta activity from the various studies. These studies are briefly described below.

- Sediment cores to a depth of $1 \mathrm{~m}$ (3.3 feet) were collected from the Par Pond system in 1984 during the Comprehensive Cooling Water Study's Radionuclide and Heavy Metal Transport Program. The mean volume-weighted cesium-137 concentration in these sediments was $8.43 \mathrm{pCi} / \mathrm{g}$ and the maximum cesium-137 concentration was $75.7 \mathrm{pCi} / \mathrm{g}$. Most of the material was in the upper $5 \mathrm{~cm}$ ( 2 inches) of 
Table 4. Comparison of activity levels measured in the P-Reactor canal system in this study and in other Par Pond cooling system studies (pCi/g).

\begin{tabular}{|c|c|c|c|c|}
\hline Study/source & $\begin{array}{l}\text { Cesium-137 } \\
\text { (pCi/g) }\end{array}$ & $\begin{array}{l}\text { Cobalt-60 } \\
\text { (pCi/g) }\end{array}$ & $\begin{array}{l}\text { Gross alpha } \\
\text { activity (pCi/g) }\end{array}$ & $\begin{array}{l}\text { Gross beta } \\
\text { activity (pCi/g) }\end{array}$ \\
\hline 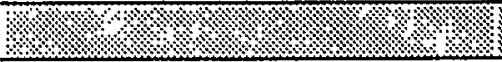 & 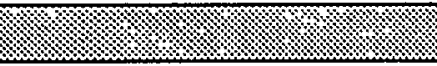 & স্য. & ২. & অ \\
\hline Pond $2 /$ this study & $\begin{array}{l}\text { range: } 0.987 \text { to } 23.9 \\
\text { mean: } 6.21\end{array}$ & $\begin{array}{l}\text { range: } \angle L L D^{1} \text { to } 0.121 \\
\text { mean: } 0.0893\end{array}$ & range: $<$ LLD to 7.6 & range: $<L L D$ to 35 \\
\hline Pond $5 /$ this study & $\begin{array}{l}\text { range: } \angle L L D \text { to } 87.4 \\
\text { mean: } 11.8\end{array}$ & $\begin{array}{l}\text { range: }<\text { LLD to } 0.176 \\
\text { mean: } 0.118\end{array}$ & range: $\angle L L D$ to 9.4 & range: <LLD to 240 \\
\hline P-Reactor Canal/this study & $\begin{array}{l}\text { range: } 0.137 \text { to } 23.7 \\
\text { mean: } 8.23 \\
\end{array}$ & $\angle L L D$ & $<L L D$ & range: $<$ LLD to 54 \\
\hline $\begin{array}{l}\text { Par Pond and Pond } B, 1984 \\
\text { CCWS }^{2}\end{array}$ & $\begin{array}{l}\text { range: }<\text { LLD to } 75.7 \\
\text { mean: } 8.43\end{array}$ & $<4$ & NA & NA \\
\hline $\begin{array}{l}\text { P-Reactor Canal, } 1984 \\
\text { CCWS }\end{array}$ & $\begin{array}{l}\text { range: }<0.2(L L D) \text { to } 17.5 \\
\text { mean: } 4.82\end{array}$ & NA & NA & NA \\
\hline $\begin{array}{l}\text { Background (Savannah } \\
\text { River, 1983-1985) }{ }^{2} \\
\end{array}$ & $<L L D$ to 1 & range: $<L L D$ to 0.4 & NA & NA \\
\hline Par Pond, SREL Study ${ }^{3}$ & mean: 100 & NA & NA & NA \\
\hline Par Pond, EMS Study 4 & range: 1.09 to 25.80 & NA & NA & NA \\
\hline Pond C, EMS Study 4 & range: 1.31 to 14.14 & NA & NA & NA \\
\hline Par Pond, ETS Study 5 & range: 0.23 to 136 & range: 0.003 to 1.31 & NA & NA \\
\hline $\begin{array}{l}\text { Background (normal levels } \\
\text { seen at SRS) } 6\end{array}$ & NA & NA & 20 & 50 \\
\hline $\begin{array}{l}\text { Background (Meyer's } \\
\text { Branch) }\end{array}$ & $<2$ (LLD) & NA & NA & NA \\
\hline
\end{tabular}

1 LLD = lower limit of detection

2 Lower 1987

3 Whicker 1991
4 WSRC 1994

5 Winn 1993

6 Peterson 1995 
soil. Cobalt-60 concentrations averaged less than $4 \mathrm{pCi} / \mathrm{g}$.

One of the coring locations was from the PReactor canal, at the west entrance to Pond 2. At that location, the cesium-137 concentration ranged from less than $0.2 \mathrm{pCi} / \mathrm{g}$ (the lower limit of detection) to $17.5 \mathrm{pCi} / \mathrm{g}$ along the length of the core, with a volume-weighted mean of 4.82 pCi/g (Lower 1987).

- Sediment samples have been collected from SRS streams and the Savannah River for routine sediment monitoring. Samples collected from the Savannah River, upstream of SRS, and from Upper Three Runs, a creek located on the SRS, provide a useful comparison because those bodies of water did not receive transuranic releases from SRS reactors. Between 1983 and 1985, cobalt-60 concentrations in these samples ranged from less than $0.2 \mathrm{pCi} / \mathrm{g}$ (the lower limit of detection) to $0.4 \mathrm{pCi} / \mathrm{g}$. These values are well within the ranges associated with global fallout. Concentrations of cesium-137 ranged from less than $0.2 \mathrm{pCi} / \mathrm{g}$ (the lower limit of detection) to $1.0 \mathrm{pCi} / \mathrm{g}$ (Lower 1987).

- In 1991, sediment cores collected by the Savannah River Ecology Laboratory from exposed and underwater areas of Par Pond showed peak cesium activity between 4 and 8 $\mathrm{cm}$ (1.5 and 3 inches) deep. Mean concentration of cesium in the top $10 \mathrm{~cm}$ ( 4 inches) of soil was about $100 \mathrm{pCi} / \mathrm{g}$ dry weight (Whicker 1991).

- In June 1991, EMS collected 8-cm (3-inch)deep soil samples along the Par Pond shoreline (at full pool) and 30-cm (12-inch)-deep cores around the Pond $C$ shoreline. Sediment samples were analyzed by gamma spectroscopy. Par Pond soils ranged from $1.09 \mathrm{pCi} / \mathrm{g}$ to $25.80 \mathrm{pCi} / \mathrm{g}$ cesium-137. Pond $\mathrm{C}$ cesium137 concentrations ranged from 1.31 to 14.14 pCi/g (WSRC 1994).
- WSRC Environmental Technology Section collected grab samples of Par Pond sediments in 1991. Cesium-137 concentrations ranged from $0.23 \mathrm{pCi} / \mathrm{g}$ to $136 \mathrm{pCi} / \mathrm{g}$. Cobalt- $60 \mathrm{con}-$ centrations ranged from $0.003 \mathrm{pCi} / \mathrm{g}$ to 1.31 pCi/g (Winn 1993).

- WSRC Environmental Restoration uses $20 \mathrm{pCi} /$ $\mathrm{g}$ alpha activity and $50 \mathrm{pCi} / \mathrm{g}$ beta activity as the levels above which the activity is considered indicative of contamination (Peterson 1995).

- The highest cesium-137 activity ever found in Par Pond sediments was $657 \mathrm{pCi} / \mathrm{g}$. Background was established from Meyer's Branch at less than $2 \mathrm{pCi} / \mathrm{g}$ (WSRC 1994).

In general, cesium-137 activities in the precooler ponds and canal are higher than background, but within the range of radioactivities in the Par Pond system. Cobalt- 60 activities in the precooler ponds appear to be within the ranges measured at background locations in previous studies.

If $20 \mathrm{pCi} / \mathrm{g}$ and $50 \mathrm{pCi} / \mathrm{g}$ are used as screening levels for gross alpha and nonvolatile beta, respectively (Peterson 1995), then nonvolatile beta activities in five samples from Pond 5 and one from the canal equaled or exceeded levels normally found in noncontaminated sites at SRS. Samples were expected to exceed the screening levels due to the history of the release of cestum- 137 and other manmade radioisotopes to the Par Pond system. Three of the highest nonvolatile beta activities, 71 $\mathrm{pCi} / \mathrm{g}, 110 \mathrm{pCi} / \mathrm{g}$ and $240 \mathrm{pCi} / \mathrm{g}$, were found in samples taken from P5-4-7 and P5-4-8. However, analytical results for three additional samples taken from the same two Pond 5 sites were less than or equal to the screening level (Appendix C). The average results for the four samples from P5-4-7 and the two samples from P5-4-8 were $67 \mathrm{pCi} / \mathrm{g}$ and $145 \mathrm{pCi} / \mathrm{g}$, respectively. The range of results could indicate an analytical problem or may reflect the nonhomogenous nature of sediment con- 
tamination. The other two highest activities on Pond 5 were $130 \mathrm{pCi} / \mathrm{g}$ and $95 \mathrm{pCi} / \mathrm{g}$, taken from P5-6-1 and P5-6-2, respectively. The "high" canal sample exhibited $54 \mathrm{pCi} / \mathrm{g}$. The nonvolatile beta activities at all other locations were less than or equal to the screening level. Gross alpha activities at all sites were also less than the screening level.

It should be noted that the screening values for alpha and beta activities probably apply to dry soil, whereas the alpha and beta results from this study are reported as wet weight. Analytical results for dry soils can be calculated using measured soil moisture content or estimated using average soil moisture content. Soil moisture was measured on 31 of the soil samples, with an average value of $37 \%$. Using the measured soil moisture content when available and the average moisture content when measured data was not available to convert the data to equivalent dry-weight activities, a total of 14 samples appear to exceed the nonvolatile beta screening level and one sample appears to exceed the gross alpha screening level. As mentioned previously, samples were expected to exceed the screening levels due to the history of the release of cesium-137 and other manmade radioisotopes to the Par Pond system. The maximum nonvolatile beta activities would increase to $99 \mathrm{pCi} / \mathrm{g}$ for Pond 2 (P2-4-2, wet-weight result of $35 \mathrm{pCi} / \mathrm{g}$ ) and 380 $\mathrm{pCi} / \mathrm{g}$ (P5-4-8, wet-weight result of $240 \mathrm{pCi} / \mathrm{g}$ ) for Pond 5, and would remain $54 \mathrm{pCi} / \mathrm{g}$ (PC-1-3) for the P-Reactor Canal. However, if the two samples from P5-4-8 are averaged, the Pond 5 maximum nonvolatile beta result would drop to $214 \mathrm{pCi} / \mathrm{g}$.

Only the sample from P5-5-1 would exceed the gross alpha screening level with a calculated result of $33 \mathrm{pCi} / \mathrm{g}$. However, when averaged with the other sample from P5-5-1, the result would be $19 \mathrm{pCi} / \mathrm{g}$, which is below the screening level.

Overall, activity levels in this study are comparable to activities measured during other studies of the Par Pond cooling system. Consequently, contamination in the P-Reactor canal system would not be expected to alter conclusions about potential risk established in risk assessments that were based on previously reported Par Pond contamination data. 


\section{References}

Crandall, B. S. 1996. Noonkester Soil Samples. Interoffice memorandum, B. S. Crandall to N. V. Halverson, April 24, 1996. Westinghouse Savannah River Company, Savannah River Site, Aiken, SC.

DiPrete, D. P. 1996. Re: Gamma Spec Analyses for Jay Noonkester. Interoffice memorandum, $D$. P. Diprete to N. V. Halverson, April 30, 1996. Westinghouse Savannah River Company, Savannah River Site, Aiken, SC.

DOE (U.S. Department of Energy). 1995 a. Environmental Assessment for the Natural Fluctuation of Water Level in Par Pond and Reduced WaterFlow in Steel Creek Below L-Lake at the Savannah River Site. DOE/EA-1070. U.S. Department of Energy Savannah River Operations Office, Aiken, SC.

DOE (U.S. Department of Energy). $1995 \mathrm{~b}$. Interim Action Record of Decision, Remedial Altemative Selection, Par Pond Unit. WSRCRP-93-1549, Rev. 0. U.S. Department of Energy Savannah River Operations Office, Aiken, SC.

Lower, M. W. 1987. Comprehensive Cooling Water Study Final Report, Volume III, Radionuclide and Heavy Metal Transport. DP-1739-3, E. I. du Pont de Nemours \& Co., Savannah River Laboratory, Aiken, SC.

Peterson, S. F. 1995. Revised Results - Analysis of ESS Soil Samples. Interoffice memorandum,
S. F. Peterson to J. V. Noonkester, SRT-ADS-951160. Westinghouse Savannah River Company, Savannah River Site, Aiken, SC.

Whicker, F. W. 1991. Radioecological Implications of the Par Pond Drawdown. Savannah River Ecology Laboratory, Aiken, SC.

Wike, L. D., R. W. Shipley, J. A. Bowers, A. L. Bryan, C. L. Cummins, B.R. del Carmen, G. P. Friday, J. E. Irwin, H. E. Mackey, Jr., J.J.Mayer, E. A. Nelson, M. H. Paller, V. A. Rogers, W. L. Specht, and E. W. Wilde. 1994. SRS Ecology, Environmental Information Document. WSRCTR-93-496. Westinghouse Savannah River Company, Savannah River Site, Aiken, SC.

Winn, W. G. 1993. Measurements of Radionuclides in Par Pond Sediments with an Underwater HPGe Detector. WSRC-TR-93-0209. Westinghouse Savannah River Company, Savannah River Site, Aiken, SC.

WSRC (Westinghouse Savannah River Company). 1994. Description of Studies in Par Pond that Contributed to the Risk Assessment Process. WSRC-RP-94-582, Westinghouse Savannah River Company, Savannah River Site, Aiken, SC.

WSRC (Westinghouse Savannah River Company). 1996. Remedial Design/Remedial Action Plan for the PAR Pond Source Control Operable Unit Interim Action. WSRC-RP-95-0384. Westinghouse Savannah River Contpany, Savannah River Site, Aiken, SC. 


\section{Appendix A}

\section{GPS Coordinates for All Sampling Transects}

Table A-1. SRS coordinates for Pond 2, Pond 5, and P-Reactor canal sampling locations.

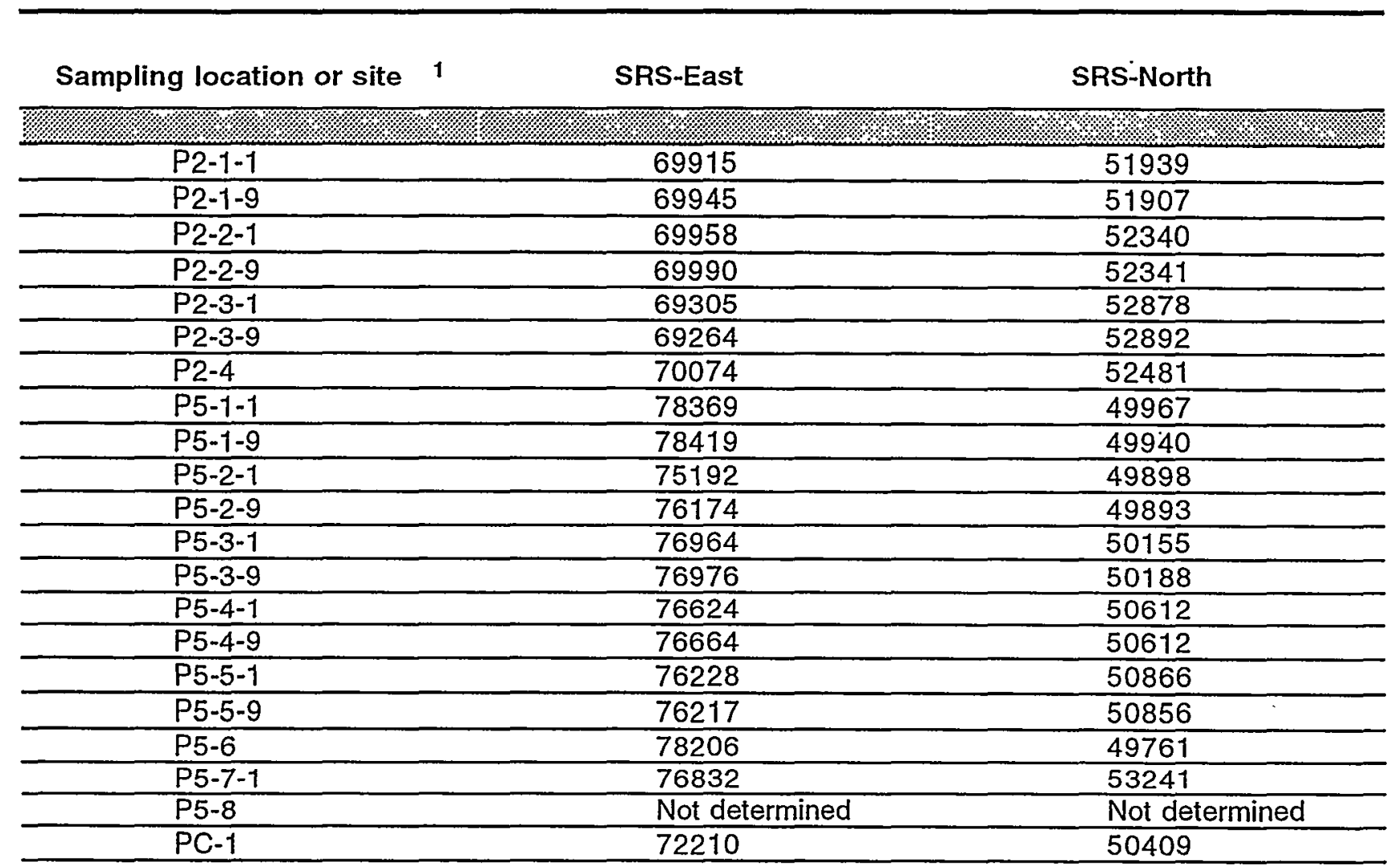

1 For Phase 1 sampling locations, coordinates of sampling points at each end of each transect were determined. For each Phase 2 sampling location, coordinates for a point estimated to be in the center of the three sampling sites were determined. 


\section{Appendix B}

\section{Analytical Detection Limits}

Table B-1. Analytical Detection Limits.

\begin{tabular}{|c|c|c|}
\hline Analyte & Laboratory 1 & Detection limit (pCi/g) \\
\hline (1., & & 4. \\
\hline Gross alpha & ADS & $2.5-10.4$ \\
\hline Gross beta & ADS & $15.8-8.5$ \\
\hline Actinium-228 & ADS & $\approx 0.5-1$ \\
\hline Actinium-228 & EMS & 0.18 \\
\hline Americium-241 & ADS & $\approx 0.2-0.3$ \\
\hline Americium-241 & EMS & 0.16 \\
\hline Antimony-124 & EMS & 0.076 \\
\hline Antimony-125 & ADS & $\approx 0.5-0.7$ \\
\hline Antimony-125 & EMS & 0.29 \\
\hline Antimony-127 & EMS & 1.7 \\
\hline Barium-133 & EMS & 0.11 \\
\hline Barium-140 & EMS & 0.57 \\
\hline Beryllium-7 & EMS & 1 \\
\hline Bismuth-212 & EMS & 0.42 \\
\hline Bismuth-214 & ADS & $\approx 0.7-1$ \\
\hline Bismuth-214 & EMS & 0.14 \\
\hline Cadmium-109 & ADS & $\approx 3-4$ \\
\hline Cadmium-109 & EMS & 1.5 \\
\hline Cesium-134 & ADS & $\approx 0.2-0.3$ \\
\hline Cesium-134 & EMS & 0.064 \\
\hline Cesium-136 & EMS & 0.094 \\
\hline Cesium-137 & $\mathrm{ADS}$ & $\approx 0.2$ \\
\hline Cesium-137 & EMS & 0.070 \\
\hline Cesium-139 & EMS & 0.074 \\
\hline Cesium-141 & EMS & 0.14 \\
\hline Cesium-144 & ADS & $\approx 0.9-1$ \\
\hline Cesium-144 & EMS & 0.49 \\
\hline Chromium-51 & EMS & 0.97 \\
\hline Cobalt-57 & EMS & 0.061 \\
\hline Cobalt-58 & EMS & 0.060 \\
\hline Cobalt-60 & ADS & $\approx 0.2$ \\
\hline Cobalt -60 & EMS & 0.045 \\
\hline
\end{tabular}

$1 \quad \mathrm{ADS}=$ WSRC Analytical Development Section; EMS = WSRC Environmental Monitoring Section. 
Table B-1. Analytical Detection Limits (continued).

\begin{tabular}{|c|c|c|}
\hline Analyte & Laboratory 1 & Detection limit (pCi/g) \\
\hline ל/ & & 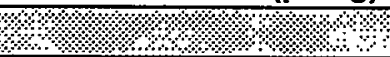 \\
\hline Europium-152 & ADS & $\approx 0.9-2$ \\
\hline Europium-152 & EMS & 0.82 \\
\hline Europium-154 & ADS & $\approx 0.2-0.3$ \\
\hline Europium-154 & EMS & 0.12 \\
\hline Europium-155 & ADS & $\approx 0.3-0.4$ \\
\hline Europium-155 & EMS & 0.18 \\
\hline Indium-114M & EMS & 0.48 \\
\hline lodine-131 & EMS & 0.27 \\
\hline Iron-59 & EMS & 0.096 \\
\hline Lead-211 & EMS & 2.7 \\
\hline Lead-212 & ADS & $=0.3-0.4$ \\
\hline Lead-212 & EMS & 0.14 \\
\hline Lead-214 & ADS & $\approx 0.6-1$ \\
\hline Lead-214 & EMS & 0.18 \\
\hline Manganese-54 & EMS & 0.062 \\
\hline Molybdenum-99 & EMS & 13 \\
\hline Neodymium-147 & EMS & 0.46 \\
\hline Neptunium-237 & ADS & $\approx 0.3-0.5$ \\
\hline Neptunium-237 & EMS & 0.43 \\
\hline Niobium-95 & EMS & 0.079 \\
\hline Niobium-95M & EMS & 3.4 \\
\hline Plutonium-239 & ADS & $\approx 2000$ \\
\hline Potassium-40 & ADS & $=2-4$ \\
\hline Potassium-40 & EMS & 0.42 \\
\hline Protactinium-234 & ADS & $\approx 0.5-0.8$ \\
\hline Radium-223 & EMS & 0.21 \\
\hline Radium-224 & ADS & $\approx 4-5$ \\
\hline Radium-224 & EMS & 2.2 \\
\hline Radium-226 & ADS & $\approx 3-5$ \\
\hline Radium-226 & EMS & 1.9 \\
\hline Radon-219 & EMS & 0.63 \\
\hline Rubidium-84 & ADS & $\approx 0.2-0.3$ \\
\hline Ruthenium-103 & EMS & 0.11 \\
\hline Ruthenium-106 & EMS & 0.64 \\
\hline Tellurium-132 & EMS & 1.3 \\
\hline Thallium-208 & ADS & $\approx 0.2-0.3$ \\
\hline Thallium-208 & EMS & 0.083 \\
\hline Thallium-210 & EMS & 0.050 \\
\hline
\end{tabular}

$1 \quad \mathrm{ADS}=$ WSRC Analytical Development Section; EMS = WSRC Environmental Monitoring Section. 
Table B-1. Analytical Detection Limits (continued).

\begin{tabular}{ccc}
\hline Analyte & Laboratory & Detection limit (pCi/g) \\
\hline Thorium-227 & EMS & (p) \\
\hline Thorium-228 & EMS & 0.55 \\
\hline Thorium-231 & EMS & 4.2 \\
\hline Thorium-234 & ADS & 0.80 \\
\hline Thorium-234 & EMS & $\approx 2-3$ \\
\hline Tin-113 & EMS & 1.1 \\
\hline Tin-126 & ADS & 0.13 \\
\hline Uranium-234 & ADS & $\approx 0.2-0.4$ \\
\hline Uranium-235 & ADS & $\approx 70-100$ \\
\hline Uranium-235 & EMS & $\approx 0.2-0.3$ \\
\hline Uranium-238 & ADS & 0.13 \\
\hline Yttrium-88 & EMS & $\approx 200-400$ \\
\hline Zinc-65 & EMS & 0.062 \\
\hline Zirconium-95 & EMS & 0.11 \\
\hline
\end{tabular}

$1 \quad \mathrm{ADS}=$ WSRC Analytical Development Section; EMS = WSRC Environmental Monitoring Section. 


\section{Appendix C}

\section{Results}

Table C-1. Units originally reported by the laboratories.

\begin{tabular}{|c|c|c|c|c|c|c|c|}
\hline \multirow[b]{2}{*}{ Sample type } & \multirow[b]{2}{*}{$\begin{array}{l}\text { Number of } \\
\text { samples }\end{array}$} & \multicolumn{3}{|c|}{$\begin{array}{l}\text { Gross alpha and } \\
\text { nonvolatile beta }\end{array}$} & \multicolumn{3}{|c|}{$\begin{array}{l}\text { Gamma } \\
\text { spectroscopy }\end{array}$} \\
\hline & & Lab & Units 1 & $\begin{array}{l}\text { Dry/wet } \\
\text { weight } 2\end{array}$ & Lab & Units 1 & $\begin{array}{l}\text { Dry/wet } \\
\text { weight } 2\end{array}$ \\
\hline$\% \%$ \% & 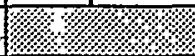 & & & & ४⿻ & 1. & \\
\hline Phase 1 & 72 & ADS & $\mathrm{pCi} / \mathrm{g}$ & wet & EMS & $\mathrm{pCi} / \mathrm{g}$ & dry \\
\hline $\begin{array}{l}\text { Phase 1 } \\
\text { duplicates }\end{array}$ & 16 & $\overline{A D S}$ & $\mathrm{dpm} / \mathrm{g}$ & dry & ADS & $\mathrm{pCi} / \mathrm{g} \& \mathrm{dpm} / \mathrm{g}$ & wet \\
\hline Phase 2 & 15 & ADS & $\mathrm{pCi} / \mathrm{g}$ & dry & ADS & $\mathrm{pCi} / \mathrm{g} \& \mathrm{dpm} / \mathrm{g}$ & wet \\
\hline
\end{tabular}

1 Conversions from $\mathrm{dpm} / \mathrm{g}$ to $\mathrm{pCi} / \mathrm{g}$ can be calculated using this conversion factor: $1 \mathrm{pCi}=2.22$ dpm.

2 Results can be converted from wet weight to dry weight or the reverse using this relationship: activity (dry weight basis) = activity (wet weight basis) / fraction of solids.

If an analyte was not detected in any sample from a particular transect, it is not included in the table of results (C-2 through C-14). For example, cobalt-60 was not found in any sample at transect P2-3. 
Table C-2. Pond 2, transect P2-1 activities.

\begin{tabular}{|c|c|c|c|c|c|c|c|c|}
\hline $\begin{array}{l}\text { Sample } \\
\text { ID }\end{array}$ & $\begin{array}{l}\text { Relative } \\
\text { elevation } \\
(\mathrm{cm})\end{array}$ & $\begin{array}{l}\text { Percent } \\
\text { solids } 1\end{array}$ & $\begin{array}{l}\text { Gross } \\
\text { alpha } \\
\text { (pCi/g } \\
\text { wet) }{ }^{2}\end{array}$ & $\begin{array}{l}\text { NV beta } \\
\text { (pCi/g } \\
\text { wet) }{ }^{2}\end{array}$ & $\begin{array}{l}\mathrm{K}-40 \\
(\mathrm{pCi} / \mathrm{g} \\
\mathrm{dry})^{3}\end{array}$ & $\begin{array}{l}\text { Co-60 } \\
(\mathrm{pCi} / \mathrm{g} \\
\text { dry })^{3}\end{array}$ & $\begin{array}{l}\text { Cs-137 } \\
\text { (pCi/g } \\
\text { dry })^{3}\end{array}$ & $\begin{array}{l}\mathrm{Tl}-208 \\
(\mathrm{pCi} / \mathrm{g} \\
\mathrm{dry})^{3}\end{array}$ \\
\hline 30 & & & 1.1 .2 .4$. & & & & কে. & \% \\
\hline P2-1-1 & -50 & & $<2.5$ & 11 & 1.19 & $\mathrm{ND}^{4}$ & 1.41 & 0.402 \\
\hline P2-1-1D & -50 & 73.9 & 3.7 & $<6$ & $\mathrm{ND}$ & ND & 5.03 & 0.279 \\
\hline P2-1-2 & -40 & & $<2.5$ & 21 & 2.88 & ND & 16.4 & 0.414 \\
\hline P2-1-3 & -30 & & $<2.5$ & 27 & 1.63 & 0.0569 & 12.2 & 0.404 \\
\hline P2-1-4 & -20 & & $<2.6$ & 12 & 1.54 & ND & 8.90 & 0.257 \\
\hline P2-1-5 & -10 & & $<2.5$ & 12 & 1.05 & ND & 7.36 & 0.115 \\
\hline P2-1-6 & 0 & & $<2.5$ & 32 & 0.832 & ND & 6.36 & 0.171 \\
\hline P2-1-7 & 10 & & $<2.5$ & 10 & 0.989 & $\mathrm{ND}$ & 5.65 & 0.266 \\
\hline P2-1-7D & 10 & 80.2 & $<2.8$ & $<5.8$ & 1.20 & ND & 4.68 & 0.166 \\
\hline P2-1-8 & 20 & & $<2.6$ & 27 & 2.52 & 0.121 & 16.9 & 0.691 \\
\hline P2-1-9 & 30 & & $<2.6$ & $<7.8$ & ND & ND & 2.79 & 0.0976 \\
\hline
\end{tabular}

\begin{tabular}{|c|c|c|c|c|c|c|c|c|}
\hline $\begin{array}{l}\text { Sample } \\
\text { ID }\end{array}$ & $\begin{array}{l}\mathrm{Pb}-212 \\
\text { (pCi/g } \\
\mathrm{dry})^{3}\end{array}$ & $\begin{array}{l}\mathrm{Pb}-214 \\
(\mathrm{pCi} / \mathrm{g} \\
\mathrm{dry})^{3}\end{array}$ & $\begin{array}{l}\mathrm{Bi}-212 \\
(\mathrm{pCi} / \mathrm{g} \\
\mathrm{dry})^{3}\end{array}$ & $\begin{array}{c}\mathrm{Bi}-214 \\
(\mathrm{pCi} / \mathrm{g} \\
\mathrm{dry})^{3}\end{array}$ & $\begin{array}{l}\text { Ra-226 } \\
\text { (pCi/g } \\
\text { dry) }{ }^{3}\end{array}$ & $\begin{array}{l}\text { Ac-228 } \\
\text { (pCi/g } \\
\text { dry })^{3}\end{array}$ & $\begin{array}{l}\text { Th-234 } \\
\text { (pCi/g } \\
\text { dry })^{3}\end{array}$ & $\begin{array}{l}\text { Am-241 } \\
\text { (pCi/g } \\
\text { dry })^{3}\end{array}$ \\
\hline & অ. & & & 1. & 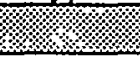 & \% & $\%$ & $1 \%$ \\
\hline P2-1-1 & 1.10 & 0.762 & 0.668 & 0.823 & 1.95 & 1.22 & ND & ND \\
\hline P2-1-1D & 0.770 & 0.628 & ND & 0.483 & ND & 0.516 & ND & ND \\
\hline P2-1-2 & 1.29 & 1.30 & 0.590 & 1.10 & 2.69 & 1.27 & ND & $\mathrm{ND}$ \\
\hline P2-1-3 & 1.24 & 1.06 & 0.834 & 1.01 & 2.57 & 1.19 & ND & 0.881 \\
\hline P2-1-4 & 0.556 & 0.685 & 0.459 & 0.545 & 2.33 & 0.606 & ND & ND \\
\hline$\overline{P 2-1-5}$ & 0.637 & 0.471 & 0.543 & 0.460 & 2.00 & 0.663 & $\mathrm{ND}$ & $\mathrm{ND}$ \\
\hline P2-1-6 & 0.643 & 0.522 & ND & 0.503 & $\mathrm{ND}$ & 0.680 & 1.09 & ND \\
\hline P2-1-7 & 0.946 & 0.713 & 0.849 & 0.666 & 3.22 & 0.866 & ND & $\mathrm{ND}$ \\
\hline P2-1-7D & 0.746 & 0.288 & ND & 0.120 & ND & ND & ND & ND \\
\hline P2-1-8 & 2.08 & 1.49 & 1.08 & 1.43 & 4.02 & 1.85 & $\mathrm{ND}^{-}$ & ND \\
\hline P2-1-9 & 0.342 & 0.289 & $\mathrm{ND}$ & 0.353 & ND & 0.424 & ND & $\mathrm{ND}$ \\
\hline
\end{tabular}

1 Percent solids $=100 \%$ moisture.

2 All gross alpha and nonvolatile (NV) beta analyses were performed by ADS and are reported as wet weight.

3 Isotopic analyses on samples identified with a $D$ at the end of the sample ID were performed by ADS. The remaining analyses were performed by EMS. All are shown as dry weight. In this and the following tables: Be-7 = beryllium-7, K-40 = potassium $-40 . \mathrm{Co}-60=$ cobalt$60, \mathrm{Cs}-137=$ cesium $-137, \mathrm{Eu}-155=$ europium $-155, \mathrm{Tl}-208=$ thallium $-208, \mathrm{~Pb}-212=$ lead 212 , $\mathrm{Pb}-214=$ lead-214, $\mathrm{Bi}-212=$ bismuth-212, Bi-214 = bismuth-214, $\mathrm{Ra}-224=$ radium224, Ra-226 $=$ radium-226, Ac-228 = actinium-228, Th-228 $=$ thorium-228, Th-231 = thorium-231, Th $234=$ thorium-234, Am-241 = americium-241, U-235 = uranium-235.

$4 \quad$ ND $=$ Not detected. 
Table C-3. Pond 2, transect P2-2 activities.

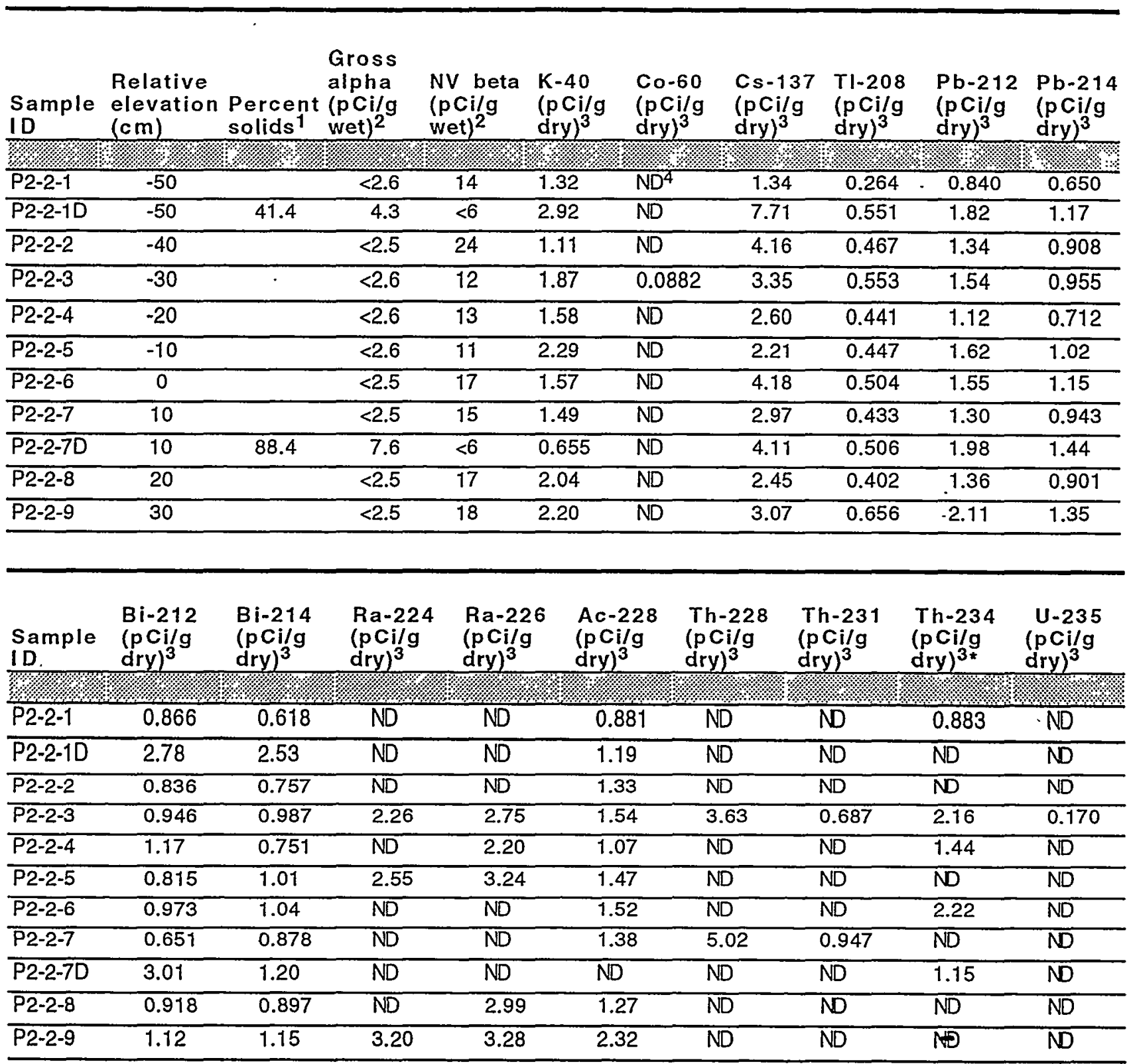

1 Percent solids $=100 \%$ moisture.

2 All gross alpha and nonvolatile (NV) beta analyses were performed by ADS and are reported as wet weight.

3 Isotopic analyses on samples identified with a $D$ at the end of the sample ID were performed by ADS. The remaining analyses were performed by EMS. All are shown as dry weight.

$4 \quad \mathrm{ND}=$ Not detected. 
Table C-4. Pond 2, transect P2-3 activities.

\begin{tabular}{|c|c|c|c|c|c|c|c|c|c|}
\hline $\begin{array}{l}\text { Sample } \\
\text { ID }\end{array}$ & $\begin{array}{l}\text { Relative } \\
\text { elevation } \\
\text { (cm) }\end{array}$ & $\begin{array}{l}\text { Percent } \\
\text { solids }{ }^{1}\end{array}$ & $\begin{array}{l}\text { Gross } \\
\text { alpha } \\
\text { (pCi/g } \\
\text { wet) }\end{array}$ & $\begin{array}{l}\text { NV beta } \\
\text { (pCi/g } \\
\text { wet) }{ }^{2}\end{array}$ & $\begin{array}{l}\mathrm{K}-40 \\
(\mathrm{pCi} / \mathrm{g} \\
\mathrm{dry})^{3}\end{array}$ & $\begin{array}{l}\text { Cs-137 } \\
(\mathrm{pCi} / \mathrm{g} \\
\mathrm{dry})^{3}\end{array}$ & $\begin{array}{l}\text { TI-208 } \\
\text { (pCi/g } \\
\text { dry })^{3}\end{array}$ & $\begin{array}{l}\mathrm{Pb}-212 \\
(\mathrm{pCi} / \mathrm{g} \\
\mathrm{dry})^{3}\end{array}$ & $\begin{array}{l}\mathrm{Pb}-214 \\
(\mathrm{pCi} / \mathrm{g} \\
\mathrm{dry})^{3}\end{array}$ \\
\hline \% & $1 \% .1$. & 1/. & I. & (3. & & & & & \\
\hline P2-3-1 & -50 & & $<2.6$ & $<7.8$ & 1.92 & 1.35 & 0.449 & 0.989 & 1.18 \\
\hline P2-3-1D & -50 & 51.8 & $<2.8$ & $<6.1$ & 3.46 & 1.92 & 0.357 & 0.681 & 1.22 \\
\hline P2-3-2 & -40 & & $<2.6$ & 14 & 2.41 & 0.987 & 0.462 & 1.43 & 1.33 \\
\hline P2-3-3 & -30 & & $<2.7$ & $<8$ & $\mathrm{ND}^{4}$ & 8.10 & 0.465 & 1.16 & 1.16 \\
\hline P2-3-4 & -20 & & $<2.7$ & 10 & 1.61 & 1.51 & 0.299 & 0.921 & 1.03 \\
\hline P2-3-5 & -10 & & $<2.7$ & 9.2 & 1.05 & 3.75 & 0.219 & 0.583 & 0.603 \\
\hline P2-3-6 & 0 & & $<2.7$ & 11 & ND & 1.26 & 0.154 & 0.281 & $\mathrm{ND}$ \\
\hline P2-3-7 & 10 & & $<2.6$ & 15 & 1.30 & 3.36 & 0.262 & 0.723 & 0.681 \\
\hline P2-3-7D & 10 & 59.3 & $<2.9$ & $<6.1$ & ND & 2.02 & 0.432 & 0.428 & 0.749 \\
\hline$P 2-3-8$ & 20 & & $<2.7$ & 10 & 1.42 & 1.56 & 0.186 & 0.653 & 0.751 \\
\hline P2-3-9 & 30 & & $<2.6$ & 9.3 & ND & 2.28 & 0.184 & 0.69 & 0.574 \\
\hline
\end{tabular}

\begin{tabular}{|c|c|c|c|c|c|c|c|c|}
\hline Sample ID & $\begin{array}{l}\mathrm{Bi}-212 \\
\text { (pCi/g } \\
\text { dry })^{3}\end{array}$ & $\begin{array}{l}\mathrm{Bi}-214 \\
(\mathrm{pCi} / \mathrm{g} \\
\mathrm{dry})^{3}\end{array}$ & $\begin{array}{l}\text { Ra-226 } \\
\text { (pCi/g } \\
\text { dry })^{3}\end{array}$ & $\begin{array}{l}\text { Ac-228 } \\
\text { (pCi/g } \\
\text { dry) }\end{array}$ & $\begin{array}{l}\text { Th-228 } \\
\text { (pCi/g } \\
\text { dry) }{ }^{3}\end{array}$ & $\begin{array}{l}\text { Th-231 } \\
\text { (pCi/g } \\
\text { dry) }{ }^{3}\end{array}$ & $\begin{array}{c}\text { Th-234 } \\
\text { (pCi/g } \\
\text { dry) }\end{array}$ & $\begin{array}{l}\text { U-235 } \\
\text { (pCi/g } \\
\text { dry) }\end{array}$ \\
\hline & & & & & & & & \\
\hline P2-3-1 & 0.673 & 1.02 & 4.56 & 1.17 & ND & $\mathrm{ND}$ & $\mathrm{ND}$ & $\mathrm{ND}$ \\
\hline P2-3-1D & ND & 1.52 & ND & ND & ND & ND & 0.531 & ND \\
\hline P2-3-2 & 1.02 & 1.28 & 2.83 & 1.44 & $\overline{N D}$ & $\overline{N D}$ & $\mathrm{ND}$ & $\mathrm{ND}$ \\
\hline P2-3-3 & $\overline{N D}$ & 1.05 & 5.99 & 1.26 & 5.11 & 0.964 & $\mathrm{ND}$ & 0.362 \\
\hline $\mathrm{P} 2-3-4$ & 1.01 & 1.14 & 4.39 & 0.862 & $\mathrm{ND}$ & ND & ND & ND \\
\hline P2-3-5 & ND & 0.563 & ND & 0.697 & ND & ND & ND & ND \\
\hline P2-3-6 & ND & 0.304 & ND & 0.276 & ND & $\mathrm{ND}$ & ND & $\mathrm{ND}$ \\
\hline P2-3-7 & 0.677 & 0.677 & 2.31 & 0.621 & 4.09 & 0.774 & $\mathrm{ND}$ & $\mathrm{ND}$ \\
\hline P2-3-7D & ND & 0.486 & ND & ND & ND & $\overline{N D}$ & $\overline{N D}$ & $\overline{N D}$ \\
\hline$P 2-3-8$ & 0.700 & 0.570 & ND & 0.728 & ND & ND & $N D$ & $\overline{N D}$ \\
\hline P2-3-9 & ND & 0.480 & ND & 0.881 & ND & $\mathrm{ND}$ & ND & ND \\
\hline
\end{tabular}

1 Percent solids $=100 \%$ moisture.

2 All gross alpha and nonvolatile (NV) beta analyses were performed by ADS and are reported as wet weight.

3 Isotopic analyses on samples identified with a $\mathrm{D}$ at the end of the sample ID were performed by ADS. The remaining analyses were performed by EMS. All are shown as dry weight.

$4 \quad \mathrm{ND}=$ Not detected. 
Table C-5. Pond 2, transect P2-4 activities.

\begin{tabular}{|c|c|c|c|c|c|c|c|}
\hline Sample ID & $\begin{array}{l}\text { Percent } \\
\text { solids } 1\end{array}$ & $\begin{array}{l}\text { Gross } \\
\text { alpha } \\
\text { (pCi/g } \\
\text { wet) } 2\end{array}$ & $\begin{array}{l}\text { NV beta } \\
\text { (pCi/g } \\
\text { wet) })^{2}\end{array}$ & $\begin{array}{l}\mathrm{K}-40 \\
\text { (pCi/g } \\
\mathrm{dry})^{3}\end{array}$ & $\begin{array}{l}\text { Co-60 } \\
\text { (pCi/g } \\
\text { dry })^{3}\end{array}$ & $\begin{array}{l}\text { Cs-137 } \\
\text { (pCi/g } \\
\text { dry) }{ }^{3}\end{array}$ & $\begin{array}{l}\text { TI-208 } \\
\text { (pCi/g } \\
\text { dry }{ }^{3}\end{array}$ \\
\hline $1 \%$ & $\% \%$ & $\%$ & \% & \% \%. & \% & $3 \%$ & \\
\hline P2-4-1 & 37.7 & $<3.0$ & 23 & $\mathrm{ND}^{4}$ & ND & 23.1 & 0.464 \\
\hline P2-4-2 & 35.3 & $<3.1$ & 35 & $\overline{N D}$ & ND & 23.9 & 0.425 \\
\hline P2-4-3 & 35.6 & $<3.1$ & 27 & 4.10 & 0.0913 & 22.6 & 0.343 \\
\hline
\end{tabular}

\begin{tabular}{|c|c|c|c|c|c|c|}
\hline Sample ID & $\begin{array}{l}\mathrm{Pb}-212 \\
(\mathrm{pCi} / \mathrm{g} \\
\mathrm{dry})^{3}\end{array}$ & $\begin{array}{l}\text { Pb-214 } \\
\text { (pCi/g } \\
\text { dry) }\end{array}$ & $\begin{array}{l}\mathrm{Bi}-212 \\
(\mathrm{pCi} / \mathrm{g} \\
\mathrm{dry})^{3}\end{array}$ & $\begin{array}{l}\mathrm{Bi}-214 \\
(\mathrm{pCi} / \mathrm{g} \\
\mathrm{dry})^{3} \\
\end{array}$ & $\begin{array}{l}\mathrm{Ra}-226 \\
\text { (pCi/g } \\
\text { dry })^{3}\end{array}$ & $\begin{array}{l}A c-228 \\
(p C i / g \\
d r y)^{3}\end{array}$ \\
\hline $18 \%$ & (1) & \% / & & $1 \% . \%$ & \% \% & 181. \\
\hline P2-4-1 & 0.597 & 1.18 & ND & 0.761 & ND & ND \\
\hline P2-4-2 & 1.01 & 1.04 & $\mathrm{ND}$ & 1.06 & $\mathrm{ND}$ & $\overline{N D}$ \\
\hline P2-4-3 & 1.03 & 1.07 & 1.71 & 1.16 & 3.03 & 1.01 \\
\hline
\end{tabular}

1 Percent solids $=100 \%$ moisture.

2 All gross alpha and nonvolatile (NV) beta analyses were performed by ADS and are reported as wet weight.

3 All isotopic analyses were performed by ADS and converted to dry weight.

$4 \quad \mathrm{ND}=$ Not detected. 
Table C-6. Pond 5, transect P5-1 activities.

\begin{tabular}{|c|c|c|c|c|c|c|c|c|c|}
\hline $\begin{array}{l}\text { Sample } \\
10\end{array}$ & $\begin{array}{l}\text { Relative } \\
\text { elevation } \\
\text { (cm) }\end{array}$ & $\begin{array}{l}\text { Percent } \\
\text { solids }{ }^{1}\end{array}$ & $\begin{array}{l}\text { Gross } \\
\text { alpha } \\
(\mathrm{pCi} / \mathrm{g} \\
\text { wet) }\end{array}$ & $\begin{array}{l}\text { NV beta } \\
(\mathrm{pCi} / \mathrm{g} \\
\text { wet })^{2}\end{array}$ & $\begin{array}{l}\mathrm{K}-40 \\
(\mathrm{pCi} / \mathrm{g} \\
\mathrm{dry})^{3}\end{array}$ & $\begin{array}{l}\text { Cs }-137 \\
\text { (pCi/g } \\
\text { dry) }\end{array}$ & $\begin{array}{l}\mathrm{Tl}-208 \\
(\mathrm{pCi} / \mathrm{g} \\
\mathrm{dry})^{3}\end{array}$ & $\begin{array}{l}\mathrm{Pb}-212 \\
(\mathrm{pCi} / \mathrm{g} \\
\text { dry })^{3}\end{array}$ & $\begin{array}{l}\mathrm{Pb}-214 \\
(\mathrm{pCi} / \mathrm{g} \\
\mathrm{dry})^{3}\end{array}$ \\
\hline \%. & $184,-1$. & (1) & & ঝ & & & ৩৷ & & \\
\hline P5-1-1 & -50 & & $<2.7$ & 16 & 0.796 & 3.32 & 0.417 & 1.15 & 0.937 \\
\hline P5-1-1D & -50 & 57.9 & 3.9 & 18 & 1.64 & 18.8 & 0.228 & 0.598 & 0.829 \\
\hline$\overline{P 5-1-2}$ & -40 & & $<2.7$ & 20 & 1.04 & 3.39 & 0.455 & 1.22 & 1.11 \\
\hline P5-1-3 & -30 & & $<2.7$ & .18 & 1.07 & 2.95 & 0.394 & 1.11 & 0.928 \\
\hline P5-1-4 & -20 & & $<2.6$ & 9.4 & $\mathrm{ND}^{4}$ & 2.39 & 0.460 & 0.991 & 0.856 \\
\hline P5-1-5 & -10 & & $<2.6$ & 12 & 0.745 & 2.87 & 0.407 & 1.09 & 0.875 \\
\hline P5-1-6 & 0 & & $<2.6$ & 14 & 0.725 & 2.36 & 0.419 & 1.13 & 0.720 \\
\hline P5-1-7 & 10 & & $<2.6$ & 18 & 0.648 & 4.29 & 0.398 & 1.10 & 0.859 \\
\hline P5-1-7D & 10 & 81.8 & 4.1 & 7.0 & 0.593 & 3.80 & 0.410 & 1.07 & 0.577 \\
\hline P5-1-8 & 20 & & $<2.7$ & 43 & 1.22 & 17.4 & 0.455 & 1.34 & 0.955 \\
\hline P5-1-9 & 30 & & $<2.7$ & $<7.4$ & 0.553 & 0.759 & 0.373 & 0.832 & 0.579 \\
\hline
\end{tabular}

\begin{tabular}{|c|c|c|c|c|c|c|c|c|}
\hline Sample ID & $\begin{array}{l}\mathrm{Bi}-212 \\
(\mathrm{pCi} / \mathrm{g} \\
\mathrm{dry})^{3}\end{array}$ & $\begin{array}{l}\mathrm{Bi}-214 \\
(\mathrm{pCi} / \mathrm{g} \\
\mathrm{dry})^{3}\end{array}$ & $\begin{array}{l}\text { Ra-224 } \\
(\mathrm{pCi} / \mathrm{g} \\
\mathrm{dry})^{3}\end{array}$ & $\begin{array}{l}\text { Ra-226 } \\
\text { (pCi/g } \\
\text { dry) }\end{array}$ & $\begin{array}{l}\text { Ac-228 } \\
\text { (pCi/g } \\
\text { dry })^{3}\end{array}$ & $\begin{array}{l}\text { Th-228 } \\
(\mathrm{pCi} / \mathrm{g} \\
\mathrm{dry})^{3}\end{array}$ & $\begin{array}{l}\text { Th-231 } \\
(\mathrm{pCi} / \mathrm{g} \\
\mathrm{dry})^{3}\end{array}$ & $\begin{array}{l}\mathrm{Th}-234 \\
(\mathrm{pCi} / \mathrm{g} \\
\mathrm{dry})^{3}\end{array}$ \\
\hline P5-1-1 & 0.916 & $\frac{1}{0.882}$ & 2.41 & $\mathrm{ND}$ & 1.16 & ND & ND & ND \\
\hline P5-1-1D & $\mathrm{ND}$ & 1.11 & ND & $\overline{N D}$ & 1.18 & $\overline{N D}$ & $\overline{N D}$ & $\overline{N D}$ \\
\hline P5-1-2 & 0.798 & 1.05 & 1.85 & 2.08 & 1.28 & $\overline{N D}$ & ND & $\overline{N D}$ \\
\hline P5-1-3 & 0.728 & 0.860 & 1.38 & 2.26 & 1.09 & $\mathrm{ND}$ & $\overline{\mathrm{ND}}$ & 1.73 \\
\hline P5-1-4 & 0.934 & 0.774 & $\overline{N D}$ & $\overline{N D}$ & 1.08 & $\overline{\mathrm{ND}}$ & $\overline{N D}$ & $\overline{N D}$ \\
\hline$P 5-1-5$ & 0.964 & 0.833 & $\mathrm{ND}$ & 3.56 & 1.07 & $\mathrm{ND}$ & $\overline{N D}$ & $\overline{N D}$ \\
\hline P5-1-6 & 1.13 & 0.703 & $\mathrm{ND}$ & ND & 1.16 & $\overline{N D}$ & ND & $\overline{N D}$ \\
\hline P5-1-7 & 0.925 & 0.802 & 1.61 & 1.90 & 1.11 & 3.67 & 0.694 & 1.40 \\
\hline P5-1-7D & $N D$ & 0.565 & 1.36 & $\overline{N D}$ & 1.17 & ND & $\mathrm{ND}$ & $\overline{N D}$ \\
\hline P5-1-8 & 1.22 & 1.04 & 2.38 & 3.58 & 1.46 & 4.90 & 0.927 & $\overline{N D}$ \\
\hline P5-1-9 & $\mathrm{ND}$ & 0.635 & 1.37 & 1.64 & 0.863 & $\mathrm{ND}$ & $\overline{N^{-}}$ & ND \\
\hline
\end{tabular}

1 Percent solids $=100 \%$ moisture.

2 All gross alpha and nonvolatile (NV) beta analyses were performed by ADS and are reported as wet weight.

3 Isotopic analyses on samples identified with a $D$ at the end of the sample ID were performed by ADS. The remaining analyses were performed by EMS. All are shown as dry weight.

$4 \quad \mathrm{ND}=$ Not detected. 
Table C-7. Pond 5, transect P5-2 activities.

\begin{tabular}{|c|c|c|c|c|c|c|c|c|c|}
\hline Sample JD & $\begin{array}{l}\text { Relative } \\
\text { elevation } \\
(\mathrm{cm})\end{array}$ & $\begin{array}{l}\text { Percent } \\
\text { solids }{ }^{1}\end{array}$ & $\begin{array}{l}\text { Gross } \\
\text { alpha } \\
\text { (pCi/g } \\
\text { wet) }\end{array}$ & $\begin{array}{l}\text { NV beta } \\
\text { (p Ci/g } \\
\text { wet) }\end{array}$ & $\begin{array}{l}\mathrm{K}-40 \\
(\mathrm{pCi} / \mathrm{g} \\
\mathrm{dry})^{3} \\
\end{array}$ & $\begin{array}{l}\text { Cs }-137 \\
(\mathrm{pCi} / \mathrm{g} \\
\mathrm{dry})^{3}\end{array}$ & $\begin{array}{l}\mathrm{TI}-208 \\
(\mathrm{pCi} / \mathrm{g} \\
\mathrm{dry})^{3} \\
\end{array}$ & $\begin{array}{l}\mathrm{Pb}-212 \\
(\mathrm{pCi} / \mathrm{g} \\
\mathrm{dry})^{3}\end{array}$ & $\begin{array}{l}\mathrm{Pb}-214 \\
(\mathrm{pCi} / \mathrm{g} \\
\text { dry) }\end{array}$ \\
\hline & & & & & א..... & & & & \\
\hline P5-2-1 & -50 & & $<2.6$ & 17 & $N^{4}$ & 4.37 & 0.405 & 1.31 & 0.881 \\
\hline P5-2-1D & -50 & 39.9 & 6.8 & $<6.1$ & 3.16 & 1.95 & 0.596 & 1.10 & 1.03 \\
\hline P5-2-2 & -40 & & $<2.6$ & 15 & ND & 2.36 & 0.343 & 0.867 & 0.561 \\
\hline P5-2-3 & -30 & & $<2.6$ & 14 & 0.917 & 0.233 & 0.422 & 1.24 & 0.821 \\
\hline P5-2-4 & -20 & & $<2.6$ & 12 & 0.772 & 0.123 & 0.472 & 1.49 & 0.829 \\
\hline P5-2-5 & -10 & & $<2.6$ & 17 & 1.05 & ND & 0.469 & 1.72 & 0.957 \\
\hline P5-2-6 & 0 & & $<2.6$ & 15 & $\mathrm{ND}$ & 0.727 & 0.556 & 1.63 & 1.04 \\
\hline P5-2-7 & 10 & & $<2.7$ & $<7.2$ & 0.963 & 0.826 & 0.458 & 1.44 & 1.04 \\
\hline P5-2-7D & 10 & 76.6 & 3.1 & $<5.9$ & 4.92 & 0.974 & 0.501 & 1.03 & 0.692 \\
\hline P5-2-8 & 20 & & $<2.7$ & $<7.3$ & 1.67 & 0.831 & 0.541 & 1.73 & 1.20 \\
\hline P5-2-9 & 30 & & $<2.7$ & $<7.4$ & $\overline{N D}$ & 0.669 & 0.940 & 2.36 & 1.58 \\
\hline
\end{tabular}

\begin{tabular}{|c|c|c|c|c|c|c|c|c|c|}
\hline $\begin{array}{l}\text { Sample } \\
\text { ID }\end{array}$ & $\begin{array}{l}\mathrm{Bi}-212 \\
(\mathrm{p} \mathrm{Ci} / \mathrm{g} \\
\mathrm{dry})^{3}\end{array}$ & $\begin{array}{l}\mathrm{Bi}-214 \\
(\mathrm{p} \mathrm{Ci/g} \\
\mathrm{dryy})^{3}\end{array}$ & $\begin{array}{l}\mathrm{Ra}-224 \\
(\mathrm{pci} / \mathrm{g} \\
\mathrm{dry})^{3}\end{array}$ & $\begin{array}{l}\text { Ra-226 } \\
(\mathrm{pCi} / \mathrm{g} \\
\mathrm{dry})^{3}\end{array}$ & $\begin{array}{l}\text { Ac-228 } \\
(\mathrm{pci} / \mathrm{g} \\
\text { dry })^{3}\end{array}$ & $\begin{array}{l}\text { Th-228 } \\
(\mathrm{pCi} / \mathrm{g} \\
\text { dry })^{3}\end{array}$ & $\begin{array}{l}\text { Th-231 } \\
(\mathrm{pci} / \mathrm{g} \\
\text { dry })^{3}\end{array}$ & $\begin{array}{l}\text { Th-234 } \\
(\mathrm{pCi} / \mathrm{g} \\
\mathrm{dry})^{3}\end{array}$ & $\begin{array}{l}\mathrm{U}-235 \\
(\mathrm{pCi} / \mathrm{g} \\
\mathrm{dry})^{3}\end{array}$ \\
\hline \% & & & & & & \% & 14. & & \\
\hline P5-2-1 & 1.06 & 0.923 & ND & 3.29 & 1.31 & $\mathrm{ND}$ & ND & ND & ND \\
\hline P5-2-1D & ND & 0.742 & $\mathrm{ND}$ & $3.61^{5}$ & $\mathrm{ND}$ & $\mathrm{ND}$ & $\overline{N D}$ & $N D$ & $0.220^{5}$ \\
\hline P5-2-2 & $\overline{\mathrm{ND}}$ & 0.565 & $\mathrm{ND}$ & $\mathrm{ND}$ & 0.856 & $\mathrm{ND}$ & $\mathrm{ND}$ & ND & ND \\
\hline P5-2-3 & 0.865 & 0.825 & ND & 2.39 & 1.20 & $\overline{N D}$ & $\overline{N D}$ & ND & $\overline{N D}$ \\
\hline P5-2-4 & 0.948 & 0.883 & ND & 1.98 & 1.42 & ND & $\overline{N D}$ & ND & $\overline{N D}$ \\
\hline P5-2-5 & 1.47 & 0.907 & 1.88 & $\mathrm{ND}$ & 1.61 & 11.1 & 2.10 & $\overline{N D}$ & $\overline{N D}$ \\
\hline$P 5-2-6$ & 1.61 & 0.899 & $\mathrm{ND}$ & ND & 1.60 & $\overline{N D}$ & $\overline{N D}$ & $\overline{N D}$ & $\overline{\mathrm{ND}}$ \\
\hline P5-2-7 & 1.12 & 0.807 & ND & 3.11 & 1.42 & ND & $\mathrm{ND}$ & $\overline{N D}$ & $\overline{N D}$ \\
\hline P5-2-7D & ND & 0.392 & $\overline{N D}$ & ND & 0.979 & $\overline{N D}$ & $\overline{N D}$ & $\overline{N D}$ & $\overline{N D}$ \\
\hline P5-2-8 & 1.44 & 1.14 & ND & $\mathrm{ND}$ & 1.81 & $\mathrm{ND}$ & ND & 2.34 & ND \\
\hline P5-2-9 & 1.79 & 1.50 & 2.50 & 2.89 & 2.46 & 7.33 & 1.39 & $\overline{N D}$ & ND \\
\hline
\end{tabular}

1 Percent solids $=100 \%$ moisture.

2 All gross alpha and nonvolatile (NV) beta analyses were performed by ADS and are reported as wet weight.

3 Isotopic analyses on samples identified with a $D$ at the end of the sample ID were performed by ADS. The remaining analyses were performed by EMS. All are shown as dry weight.

$4 \quad \mathrm{ND}=$ Not detected

5 Part of an ADS undetermined solution. 
Table C-8. Pond 5, transect P5-3 activities.

\begin{tabular}{|c|c|c|c|c|c|c|c|c|}
\hline $\begin{array}{l}\text { Sample } \\
\text { ID }\end{array}$ & $\begin{array}{l}\text { Relative } \\
\text { elevation } \\
\text { (cm) }\end{array}$ & $\begin{array}{l}\text { Percent } \\
\text { solids } 1\end{array}$ & $\begin{array}{l}\text { Gross } \\
\text { alpha } \\
\text { (pCi/g } \\
\text { wet) } 2\end{array}$ & $\begin{array}{l}\text { NV beta } \\
\text { (pCi/g } \\
\text { wet) }{ }^{2}\end{array}$ & $\begin{array}{l}\mathrm{K}-40 \\
(\mathrm{pCi} / \mathrm{g} \\
\mathrm{dry})^{3}\end{array}$ & $\begin{array}{l}\text { Co-60 } \\
\text { (pCi/g } \\
\text { dry) }\end{array}$ & $\begin{array}{l}\text { Cs-137 } \\
\text { (pCi/g } \\
\text { dry })^{3} \\
\end{array}$ & $\begin{array}{l}\text { TI-208 } \\
(\mathrm{pCi} / \mathrm{g} \\
\mathrm{dry})^{3}\end{array}$ \\
\hline & 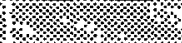 & & \% & \% & & & & (19: \\
\hline P5-3-1 & -50 & & 5.5 & $<7.3$ & $\mathrm{ND}^{4}$ & ND & 2.52 & 0.316 \\
\hline P5-3-1D & -50 & 74.3 & 3.1 & $<6.0$ & 1.40 & ND & 1.66 & 0.335 \\
\hline P5-3-2 & -40 & & $<2.7$ & $<7.3$ & 0.832 & ND & 3 & 0.373 \\
\hline$\overline{\text { P5-3-3 }}$ & -30 & & 4.2 & $<7.3$ & ND & ND & 5.55 & 0.329 \\
\hline P5-3-4 & -20 & & $<2.7$ & $<7.3$ & 0.800 & ND & 6 & 0.346 \\
\hline P5-3-5 & -10 & & $<2.7$ & $<7.4$ & 0.592 & ND & 1.97 & 0.237 \\
\hline P5-3-6 & 0 & & 2.8 & $<7.4$ & ND & ND & 0.359 & 0.132 \\
\hline P5-3-7 & 10 & & $<2.7$ & $<7.4$ & $\mathrm{ND}$ & ND & 1.08 & 0.270 \\
\hline P5-3-7D & 10 & 81.2 & $<2.7$ & $<5.9$ & $\overline{N D}$ & $\overline{N D}$ & 0.826 & 0.395 \\
\hline P5-3-8 & 20 & & $<2.7$ & $<7.2$ & $\mathrm{ND}$ & 0.0604 & 11.7 & 0.384 \\
\hline P5-3-9 & 30 & & $<2.8$ & $<7.4$ & ND & ND & 2.66 & 0.372 \\
\hline
\end{tabular}

\begin{tabular}{|c|c|c|c|c|c|c|c|}
\hline Sample ID & $\begin{array}{l}\mathrm{Pb}-212 \\
\text { (pCi/g } \\
\text { dry) }{ }^{3}\end{array}$ & $\begin{array}{l}\mathrm{Pb}-214 \\
\text { (pCi/g } \\
\text { dry })^{3}\end{array}$ & $\begin{array}{l}\mathrm{Bi}-212 \\
(\mathrm{pCi} / \mathrm{g} \\
\mathrm{dry})^{3}\end{array}$ & $\begin{array}{l}\mathrm{Bi}-214 \\
(\mathrm{pCi} / \mathrm{g} \\
\mathrm{dry})^{3}\end{array}$ & $\begin{array}{l}\text { Ra-226 } \\
\text { (pCi/g } \\
\text { dry })^{3}\end{array}$ & $\begin{array}{l}\mathrm{Ac}-228 \\
(\mathrm{pCi} / \mathrm{g} \\
\mathrm{dry})^{3}\end{array}$ & $\begin{array}{l}\text { U-235 } \\
\text { (pCi/g } \\
\text { dry })^{3}\end{array}$ \\
\hline 3. & & א. & & & & & \% \\
\hline P5-3-1 & 0.873 & 0.849 & 0.504 & 0.712 & 1.91 & 0.923 & ND \\
\hline P5-3-1D & 0.643 & 0.627 & $\mathrm{ND}$ & 0.703 & $1.56^{5}$ & 0.724 & $0.0949^{5}$ \\
\hline P5-3-2 & 0.967 & 0.896 & 0.894 & 0.838 & $\mathrm{ND}$ & 1.12 & 0.229 \\
\hline P5-3-3 & 0.942 & 0.845 & 0.547 & 0.822 & $\mathrm{ND}$ & 0.958 & $\mathrm{ND}$ \\
\hline P5-3-4 & 0.808 & 0.792 & 0.993 & 0.784 & 3.27 & 1.02 & ND \\
\hline P5-3-5 & 0.447 & 0.466 & 0.440 & 0.433 & $\mathrm{ND}$ & 0.525 & ND \\
\hline P5-3-6 & 0.323 & 0.390 & 0.533 & 0.292 & ND & 0.350 & ND \\
\hline P5-3-7 & 0.815 & 0.606 & 0.552 & 0.719 & ND & 0.887 & $\mathrm{ND}$ \\
\hline P5-3-7D & 0.935 & 0.372 & ND & 0.234 & $1.01^{5}$ & 1.01 & $0.0617^{5}$ \\
\hline P5-3-8 & 0.911 & 1.00 & 0.808 & 0.873 & ND & $0.99 T$ & $\mathrm{ND}$ \\
\hline P5-3-9 & 0.840 & 0.852 & 0.609 & 0.678 & $\overline{N D}$ & 0.893 & $\overline{N D}$ \\
\hline
\end{tabular}

1 Percent solids $=100 \%$ moisture.

2 All gross alpha and nonvolatile (NV) beta analyses were performed by ADS and are reported as wet weight.

3 Isotopic analyses on samples identified with a $\mathrm{D}$ at the end of the sample ID were performed by ADS. The remaining analyses were performed by EMS. All are shown as dry weight.

$4 \quad \mathrm{ND}=$ Not detected.

5 Part of an ADS undetermined solution. 
Table C-9. Pond 5, transect P5-4 activities.

\begin{tabular}{|c|c|c|c|c|c|c|c|c|c|}
\hline Sample ID & $\begin{array}{l}\text { Sample } \\
\text { depth }\end{array}$ & $\begin{array}{l}\text { Percent } \\
\text { solids } 1\end{array}$ & $\begin{array}{l}\text { Gross } \\
\text { alpha } \\
\text { (pCi/g } \\
\text { wet) }\end{array}$ & \multicolumn{2}{|c|}{$\begin{array}{l}\text { NV beta } \\
\text { (pCi/g } \\
\text { wet) }\end{array}$} & $\begin{array}{l}\mathrm{K}-40 \\
(\mathrm{pCi} / \mathrm{g} \\
\mathrm{dry})^{3}\end{array}$ & $\begin{array}{l}\text { Co-60 } \\
\text { (pCi/g } \\
\text { dry })^{3}\end{array}$ & $\begin{array}{l}\text { Cs-137 } \\
\text { (pCilg } \\
\text { dry }{ }^{3}\end{array}$ & $\begin{array}{l}\mathrm{Tl}-208 \\
\text { (pCi/g } \\
\mathrm{dry})^{3}\end{array}$ \\
\hline $48 \%$ & & 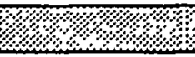 & পধ & ২ে & 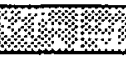 & $1 \%$ & $13 \%$ & & \\
\hline P5-4-1 & -50 & & $<2.7$ & & & 1.37 & $\mathrm{ND}^{4}$ & 6.49 & 0.352 \\
\hline P5-4-1D & -50 & 59.7 & 3.2 & & & 1.83 & $\mathrm{ND}$ & 6.42 & 0.223 \\
\hline P5-4-2 & -40 & & $<2.7$ & & & 1.20 & ND & 5.06 & 0.388 \\
\hline P5-4-3 & -30 & & $<2.7$ & & & 1.04 & ND & 2.32 & 0.330 \\
\hline P5-4-4 & -20 & & $<2.7$ & & & 0.695 & ND & 6.53 & 0.373 \\
\hline P5-4-5 & -10 & & $<2.8$ & & & 0.687 & ND & 0.933 & 0.305 \\
\hline P5-4-6 & 0 & & $<2.7$ & & & ND & ND & 3.66 & 0.364 \\
\hline P5-4-7 & 10 & & $<2.7$ & & & 3.48 & ND & 56.7 & 0.584 \\
\hline P5-4-7D & 10 & 55.0 & 9.4 & & 0 & 9.44 & ND & 73.8 & 0.440 \\
\hline P5-4-7 Phase 2 & 10 & $100^{5}$ & $<5.2$ & & 9 & 3.18 & $\mathrm{ND}$ & 43.0 & 0.407 \\
\hline P5-4-7D Phase 2 & 10 & 94.8 & $<10.4$ & & 1 & 4.09 & ND & 45.9 & 0.448 \\
\hline P5-4-8 & 20 & & $<2.8$ & & & 5.53 & 0.176 & 87.4 & 0.601 \\
\hline P5-4-8 Phase 2 & 20 & $100^{6}$ & $<4.2$ & & 9 & 5.37 & ND & 69.6 & 0.435 \\
\hline P5-4-9 & 30 & & $<2.7$ & & & 1.26 & ND & 25.3 & 0.409 \\
\hline Sample ID & $\begin{array}{l}\mathrm{Pb}-212 \\
(\mathrm{pCi} / \mathrm{g} \\
\mathrm{dry})^{3}\end{array}$ & $\begin{array}{l}\mathrm{Pb}-214 \\
\text { (pCi/g } \\
\mathrm{dry})^{3}\end{array}$ & & & $\begin{array}{l}\mathrm{Bi}-214 \\
(\mathrm{pCi} / \mathrm{g} \\
\mathrm{dry})^{3}\end{array}$ & & $\begin{array}{l}\mathrm{Ra}-226 \\
(\mathrm{pCi} / \mathrm{g} \\
\mathrm{dry})^{3}\end{array}$ & $\begin{array}{l}\text { Ac-228 } \\
\text { (pCi/g } \\
\text { dry) }\end{array}$ & $\begin{array}{l}\text { Th-234 } \\
\text { (pCi/g } \\
\text { dry) }\end{array}$ \\
\hline & & & & & & & & & 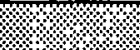 \\
\hline P5-4-1 & 0.946 & 0.911 & & 36 & 0.969 & & ND & 1.02 & ND \\
\hline P5-4-1D & 0.849 & 0.611 & & & 0.827 & & $\overline{N D}$ & $\overline{N D}$ & 1.52 \\
\hline P5-4-2 & 1.02 & 0.878 & & $\overline{58}$ & 0.808 & & ND & 1.10 & ND \\
\hline$\overline{P 5-4-3}$ & 0.883 & 0.765 & & 09 & 0.741 & & 3.08 & 1.01 & ND \\
\hline P5-4-4 & 1.01 & 0.942 & & 823 & 0.818 & & $\overline{N D}$ & 1.09 & ND \\
\hline P5-4-5 & 0.657 & 0.721 & & 679 & 0.623 & & ND & 0.871 & ND \\
\hline P5-4-6 & 1.14 & 0.686 & & 905 & 0.825 & & ND & 1.01 & ND \\
\hline P5-4-7 & 1.58 & 1.06 & & 44 & 1.32 & & ND & $1.47-$ & $\overline{N D}$ \\
\hline P5-4-7D & 1.61 & 1.73 & & & 1.47 & & ND & ND & ND \\
\hline P5-4-7 Phase 2 & 0.978 & 1.07 & & & 0.961 & & ND & 1.33 & ND \\
\hline P5-4-7D Phase 2 & 1.02 & 0.745 & & & 0.930 & & ND & ND & ND \\
\hline P5-4-8 & 1.22 & 2 & & 18 & 1.70 & & 8.05 & 1.73 & $\mathrm{ND}$ \\
\hline P5-4-8 Phase 2 & 1.20 & 0.123 & & & 1.15 & & ND & ND & ND \\
\hline P5-4-9 & 1.15 & 1.20 & & 987 & 1.13 & & ND & 1.14 & ND \\
\hline
\end{tabular}

$1 \quad$ Percent solids $=100 \%$ moisture.

2 All gross alpha and nonvolatile (NV) beta analyses were performed by ADS and are reported as wet weight.

3 Isotopic analyses on samples identified with a $D$ at the end of the sample ID were performed by ADS. The remaining analyses were performed by EMS. All are shown as dry weight.

$4 \quad$ ND $=$ Not detected.

5 Actually reported as $108.54 \%$.

6 Actually reported as $109.56 \%$. 
Table C-10. Pond 5, transect P5-5 activities.

\begin{tabular}{|c|c|c|c|c|c|c|c|c|}
\hline $\begin{array}{l}\text { Sample } \\
\text { ID }\end{array}$ & $\begin{array}{l}\text { Relative } \\
\text { elevation } \\
\text { (cm) }\end{array}$ & $\begin{array}{l}\text { Percent } \\
\text { solids } 1\end{array}$ & $\begin{array}{l}\text { Gross } \\
\text { alpha } \\
\text { (pCi/g } \\
\text { wet) }\end{array}$ & $\begin{array}{l}\text { NV beta } \\
\text { (pCi/g } \\
\text { wet) }{ }^{2}\end{array}$ & $\begin{array}{l}\mathrm{K}-40 \\
(\mathrm{pCi} / \mathrm{g} \\
\mathrm{dry})^{3} \\
\end{array}$ & $\begin{array}{l}\text { Cs-137 } \\
\text { (pCi/g } \\
\text { dry })^{3}\end{array}$ & $\begin{array}{l}\mathrm{Tl}-208 \\
(\mathrm{pCi} / \mathrm{g} \\
\mathrm{dry})^{3}\end{array}$ & $\begin{array}{l}\mathrm{Pb}-212 \\
(\mathrm{pCi} / \mathrm{g} \\
\mathrm{dry})^{3}\end{array}$ \\
\hline & & & (1. & \% & & (1.3. & & \\
\hline P5-5-1 & -50 & & $<2.7$ & $<7.3$ & 1.85 & 18.6 & 0.228 & 0.982 \\
\hline P5-5-1D & -50 & 24.5 & 8.2 & 12 & 7.10 & 30.7 & $\mathrm{ND}^{4}$ & 0.841 \\
\hline P5-5-2 & -40 & & $<2.7$ & $<7.3$ & $\mathrm{ND}$ & 5.83 & 0.272 & 0.769 \\
\hline P5-5-3 & -30 & & $<2.7$ & $<7.3$ & ND & 3.46 & 0.144 & 0.356 \\
\hline P5-5-4 & -20 & & $<2.7$ & $<7.4$ & $\mathrm{ND}$ & 4.67 & 0.188 & 0.497 \\
\hline P5-5-5 & -10 & & $<2.8$ & $<7.4$ & ND & 1.66 & 0.0772 & ND \\
\hline P5-5-6 & 0 & & $<2.7$ & $<7.4$ & ND & 0.872 & $\mathrm{ND}$ & $\mathrm{ND}$ \\
\hline P5-5-7 & 10 & & $<2.8$ & $<7.4$ & ND & 1.18 & 0.0945 & 0.243 \\
\hline P5-5-7D & 10 & 60.4 & $<2.7$ & 6 & 0.288 & 1.39 & $\mathrm{ND}$ & $\mathrm{ND}$ \\
\hline P5-5-8 & 20 & & $<2.7$ & $<7.3$ & ND & 0.415 & 0.0456 & 0.158 \\
\hline P5-5-9 & 30 & & $<2.7$ & $<7.4$ & ND & 0.161 & ND $\cdot$ & 0.0481 \\
\hline $\begin{array}{l}\text { Sample } \\
\text { ID }\end{array}$ & $\begin{array}{l}\mathrm{Pb}-214 \\
(\mathrm{pCi} / \mathrm{g} \\
\mathrm{dry})^{3}\end{array}$ & $\begin{array}{l}\mathrm{Bi}-212 \\
(\mathrm{pCi} / \mathrm{g} \\
\mathrm{dry})^{3}\end{array}$ & $\begin{array}{l}\mathrm{Bi}-214 \\
(\mathrm{pCi} / \mathrm{g} \\
\mathrm{dry})^{3}\end{array}$ & $\begin{array}{l}\mathrm{Ra}-224 \\
(\mathrm{pCi} / \mathrm{g} \\
\mathrm{dry})^{3}\end{array}$ & $\begin{array}{l}\mathrm{Ra}-226 \\
(\mathrm{pCi} / \mathrm{g} \\
\mathrm{dry})^{3}\end{array}$ & $\begin{array}{l}\text { Ac-228 } \\
(\mathrm{pCi} / \mathrm{g} \\
\mathrm{dry})^{3}\end{array}$ & $\begin{array}{l}\text { Th-234 } \\
(\mathrm{pCi} / \mathrm{g} \\
\mathrm{dry})^{3}\end{array}$ & $\begin{array}{l}\text { U-235 } \\
\text { (pCi/g } \\
\text { dry) }{ }^{3}\end{array}$ \\
\hline P5-5-1 & 0.812 & 0.638 & 0.867 & ND & ND & 1.17 & ND & ND \\
\hline P5-5-1D & 3.01 & ND & 1.82 & ND & $1.52^{5}$ & ND & 2.81 & $0.0927^{5}$ \\
\hline P5-5-2 & 0.717 & $\mathrm{ND}$ & 0.722 & ND & ND & 0.728 & ND & ND \\
\hline P5-5-3 & 0.474 & $\overline{N D}$ & 0.395 & ND & 1.87 & 0.474 & $\mathrm{ND}$ & ND \\
\hline P5-5-4 & 0.524 & ND & 0.444 & $\mathrm{ND}$ & 2.10 & 0.541 & $\mathrm{ND}$ & ND \\
\hline P5-5-5 & 0.199 & 0.352 & 0.220 & ND & $\mathrm{ND}$ & ND & ND & ND \\
\hline P5-5-6 & 0.191 & $\mathrm{ND}$ & 0.173 & ND & ND & $\mathrm{ND}$ & $\mathrm{ND}$ & ND \\
\hline P5-5-7 & 0.139 & ND & 0.230 & 2.76 & $\mathrm{ND}$ & ND & $\mathrm{ND}$ & ND \\
\hline P5-5-7D & ND & ND & 0.343 & ND & ND & ND & ND & ND \\
\hline P5-5-8 & 0.135 & $\mathrm{ND}$ & 0.117 & ND & ND & ND & $\mathrm{ND}^{-}$ & ND \\
\hline P5-5-9 & 0.0669 & ND & ND & ND & ND & ND & ND & ND \\
\hline
\end{tabular}

1 Percent solids $=100 \%$ moisture.

2 All gross alpha and nonvolatile (NV) beta analyses were performed by ADS and are reported as wet weight.

3 Isotopic analyses on samples identified with a $D$ at the end of the sample ID were performed by ADS. The remaining analyses were performed by EMS. All are shown as dry weight.

$4 \quad \mathrm{ND}=$ Not detected.

5 Part of an ADS undetermined solution. 
Table C-11. Pond 5, transect P5-6 activities.

\begin{tabular}{|c|c|c|c|c|c|}
\hline Sample ID & $\begin{array}{l}\text { Percent } \\
\text { Solids } 1 \\
\end{array}$ & $\begin{array}{l}\text { Gross alpha } \\
\text { (pCi/g wet) } 2\end{array}$ & $\begin{array}{l}\text { NV beta } \\
\text { (pCi/g wet) } 2\end{array}$ & $\begin{array}{l}\text { K-40 } \\
\text { (pCi/g dry) }\end{array}$ & $\begin{array}{l}\text { Cs-137 } \\
\text { (pCi/g dry) }\end{array}$ \\
\hline 11\% & $1121 \% 12$ & $\because 11112$ & $1.2 \%$ & "1. & 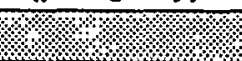 \\
\hline P5-6-1 & 81.1 & $<3$ & 130 & $N D^{4}$ & 39.1 \\
\hline P5-6-2 & 72.7 & $<3.1$ & 95 & 4.10 & 56.5 \\
\hline P5-6-3 & 35.9 & $<3$ & 26 & ND & 28.1 \\
\hline Sample ID & $\begin{array}{l}\text { T1-208 } \\
(\text { (pCi/g dry })^{3}\end{array}$ & $\begin{array}{l}\mathrm{Pb}-212 \\
\text { (pCi/g dry) }^{3}\end{array}$ & $\begin{array}{l}\mathrm{Pb}-214 \\
\text { (pCi/g dry) } 3\end{array}$ & $\begin{array}{l}\text { Bi-214 } \\
\text { (pCi/g dry) }^{3}\end{array}$ & $\begin{array}{l}\text { Ac-228 } \\
\text { (pCi/g dry) }{ }^{3}\end{array}$ \\
\hline 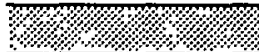 & 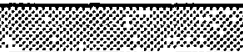 & & 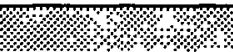 & (19.8. & (4) \\
\hline P5-6-1 & 0.285 & 0.564 & 1.01 & 1.07 & 1.51 \\
\hline$P 5-6-2$ & 0.347 & 0.818 & 1 & 0.988 & $\overline{N D}$ \\
\hline P5-6-3 & ND & 0.318 & 0.518 & ND & ND \\
\hline
\end{tabular}

1 Percent solids $=100 \%$ moisture.

2 All gross alpha and nonvolatile (NV) beta analyses were performed by ADS and are reported as wet weight.

3 Isotopic analyses on samples identified with a $\mathrm{D}$ at the end of the sample ID were performed by ADS. The remaining analyses were performed by EMS. All are shown as dry weight.

$4 \mathrm{ND}=$ Not detected. 
Table C-12. Pond 5, transect P5-7 activities.

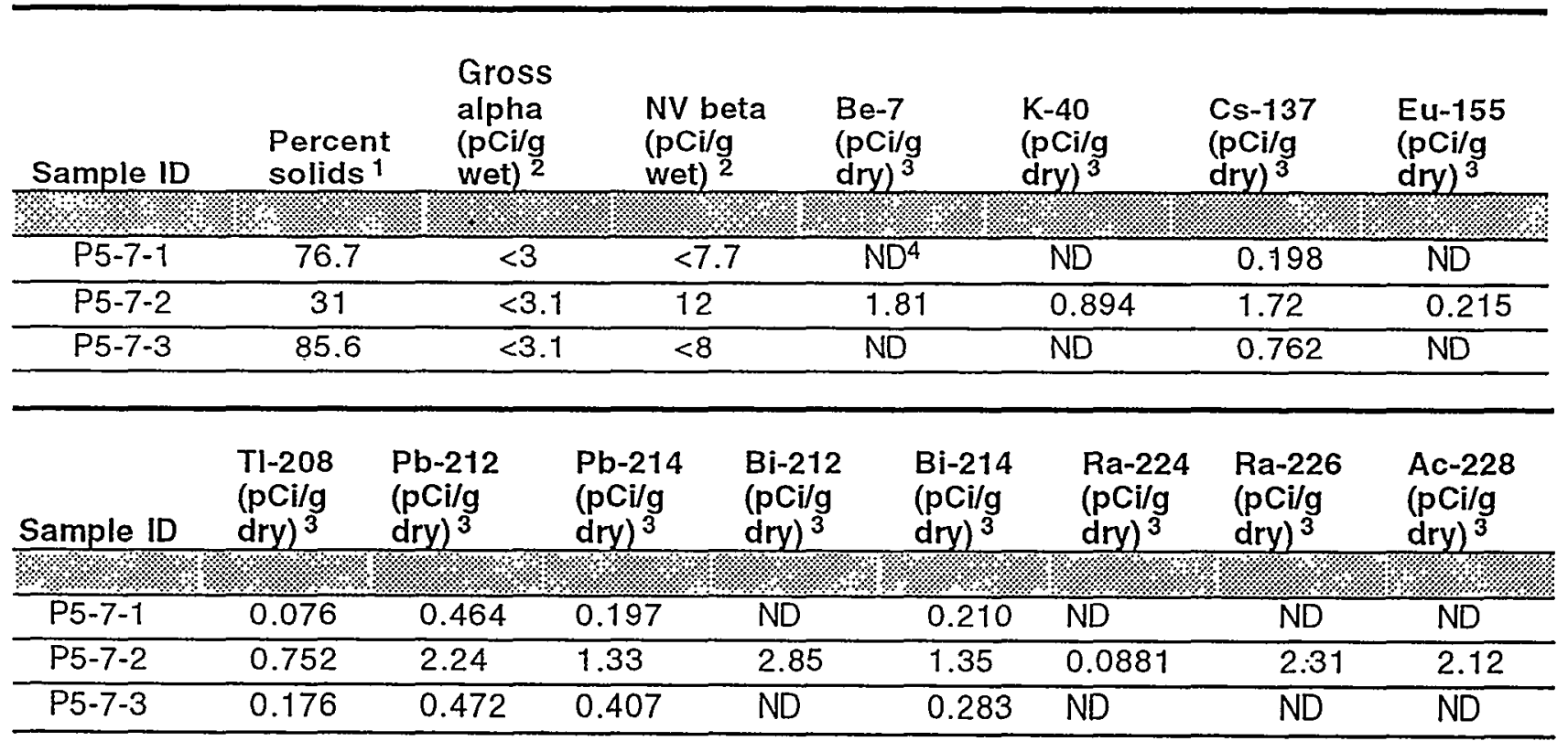

1 Percent solids $=100 \%$ moisture.

2 All gross alpha and nonvolatile (NV) beta analyses were performed by ADS and are reported as wet weight.

3 Isotopic analyses on samples identified with a $\mathrm{D}$ at the end of the sample ID were performed by ADS. The remaining analyses were performed by EMS. All are shown as dry weight.

$4 \quad \mathrm{ND}=$ Not detected. 
Table C-13. Pond 5, location P5-8 activities.

\begin{tabular}{|c|c|c|c|c|c|c|}
\hline Sample ID & $\begin{array}{l}\text { Percent } \\
\text { solids } 1\end{array}$ & $\begin{array}{l}\text { Gross } \\
\text { alpha } \\
\text { (pCi/g } \\
\text { wet) }{ }^{2}\end{array}$ & $\begin{array}{l}\text { NV beta } \\
\text { (pCi/g } \\
\text { wet) }{ }^{2}\end{array}$ & $\begin{array}{l}\mathrm{Pb}-212 \\
(\mathrm{pCi} / \mathrm{g} \\
\mathrm{dry})^{3}\end{array}$ & $\begin{array}{l}\mathrm{Pb}-214 \\
\text { (pCi/g } \\
\text { dry) }\end{array}$ & $\begin{array}{l}\mathrm{Bi}-214 \\
(\mathrm{pCi} / \mathrm{g} \\
\mathrm{dry})^{3}\end{array}$ \\
\hline 4 & \% & 8 & প & 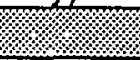 & $\%$ & \\
\hline P5-8-1 & 26.6 & $<3.2$ & $<8.5$ & 0.496 & 0.959 & 0.748 \\
\hline P5-8-2 & 22.6 & $<3.2$ & 20 & 0.562 & 1.16 & $\mathrm{ND}^{4}$ \\
\hline P5-8-3 & 20.2 & $<3.2$ & 9.5 & ND & 1.34 & ND \\
\hline
\end{tabular}

1 Percent solids $=100 \%$ moisture.

2 All gross alpha and nonvolatile (NV) beta analyses were performed by ADS and are reported as wet weight.

3 Isotopic analyses on samples identified with a $D$ at the end of the sample ID were performed by ADS. The remaining analyses were performed by EMS. All are shown as dry weight.

$4 \mathrm{ND}=$ Not detected. 
Table C-14. P-Reactor canal, location PC-1 activities.

\begin{tabular}{|c|c|c|c|c|c|c|}
\hline Sample ID & $\begin{array}{l}\text { Percent } \\
\text { solids } 1\end{array}$ & $\begin{array}{l}\text { Gross } \\
\text { alpha } \\
\text { (pCi/g } \\
\text { wet) }\end{array}$ & $\begin{array}{l}\text { NV beta } \\
\text { (pCi/g } \\
\text { wet) }{ }^{2}\end{array}$ & $\begin{array}{l}\text { K-40 } \\
\text { (pCi/g } \\
\text { dry) }{ }^{3}\end{array}$ & $\begin{array}{l}\text { Cs-137 } \\
\text { (pCi/g } \\
\text { dry) }\end{array}$ & $\begin{array}{l}\text { TI-208 } \\
\text { (pCi/g } \\
\text { dry) }{ }^{3}\end{array}$ \\
\hline \multicolumn{7}{|c|}{ १. } \\
\hline PC-1-1 & 85.1 & $<3.1$ & 25 & $\mathrm{ND}^{4}$ & 0.137 & 0.397 \\
\hline $\mathrm{PC}-1-2$ & 98.8 & $<3.1$ & $<7.9$ & ND & 0.865 & 0.287 \\
\hline PC-1-3 & $100^{5}$ & $<3$ & 54 & 4.65 & 23.7 & 0.556 \\
\hline Sample ID & $\begin{array}{l}\mathrm{Pb}-212 \\
\text { (pCi/g } \\
\mathrm{dry})^{3}\end{array}$ & $\begin{array}{l}\mathrm{Pb}-214 \\
\text { (pCi/g } \\
\text { dry) }{ }^{3}\end{array}$ & $\begin{array}{l}\mathrm{Bi}-212 \\
(\mathrm{pCi} / \mathrm{g} \\
\mathrm{dry})^{\frac{3}{3}}\end{array}$ & $\begin{array}{l}\mathrm{Bi}-214 \\
(\mathrm{pCi} / \mathrm{g} \\
\mathrm{dry})^{3}\end{array}$ & $\begin{array}{l}\mathrm{Ra}-226 \\
\text { (pCi/g } \\
\mathrm{dry})^{\frac{3}{3}}\end{array}$ & $\begin{array}{l}A c-228 \\
\text { (pCi/g } \\
\text { dry })^{3}\end{array}$ \\
\hline $1 \%$ & & & & & $1 \% \%$ & \\
\hline PC-1-1 & 1.06 & 0.593 & 1.88 & 0.620 & $1.03^{6}$ & 0.938 \\
\hline PC-1-2 & 0.654 & 0.556 & 1.30 & 0.523 & ND & 0.639 \\
\hline PC-1-3 & 1.48 & 1.16 & $\mathrm{ND}$ & 1.42 & ND & 1.44 \\
\hline
\end{tabular}

1 Percent solids $=100 \%$ moisture.

2 All gross alpha and nonvolatile (NV) beta analyses were performed by ADS and are reported as wet weight.

3 Isotopic analyses on samples identified with $\mathrm{D}$ at the end of the sample ID were performed by ADS. The remaining analyses were performed by EMS. All are shown as dry weight.

$4 \quad \mathrm{ND}=$ Not detected.

5 Actually reported as $103.9 \%$.

6 Part of an ADS undetermined solution. 